
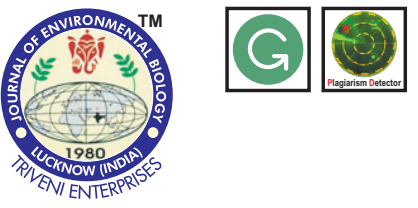

\title{
Relationship between land use and land classification in the Tahtalı Dam Protection Basin (İzmir, Turkey)
}

\section{Authors Info}

\section{A.E. Gülersoy ${ }^{1 *}$ N. Gümüş',} M.A. Çelik' and A. IIhan ${ }^{3}$

'Social Studies Dept. Buca Faculty of Education, Dokuz Eylul University, Izmir, 35150, Turkey

${ }^{2}$ Department of Geography, Faculty of Arts and Sciences, Kilis 7 Aralik University, Kilis, 79000, Turkey

${ }^{3}$ Department of Social Studies, Faculty of Education, Artvin Coruh University, Artvin, 08100, Turkey

*Corresponding Author Email : gulersoy74@gmail.com

Key words

GIS-Remote sensing,

Land capability classes,

Land use,

Tahtalı dam protection basin

\section{Publication Info}

Paper received : 25.08.2016

Revised received : 20.06.2016

Accepted : 27.06.2017

\section{Abstract}

Aim: The study aims to assess the relationship between land use and the land classes in the Tahtalı Dam Protection Basinin terms of sustainable use of natural resources.

Methodology: Landsat satellite images were used to determine the current land use and remote sensing was employed to process these images.

Results: Land capability classification demonstrates the natural potential of an area. Class I, II, and III lands that are agriculturally important cover $30 \%$ of the basin. Class IV, Class VI, and Class VII lands account for $6 \%, 21 \%$, and $42 \%$ of the basin, respectively. Class $V$ lands covered a very small area in the basin and they were not taken into consideration. Finally, Class VIII lands take up merely $1 \%$ of the area. The most important kinds of land use in the basin are forests-maquis-garrigues $(62.8 \%)$, fields $(28.7 \%)$, residential areas $(3.5 \%)$, greenhouses $(2.3 \%)$, and water surface areas $(2.7 \%)$. There is a mismatch between the land capability classes and their use. In fact, $31 \%$ (of $200 \mathrm{~km}^{2}$ ) of the Tahtalı Dam Protection Basin is misused. Failure to use lands in line with their capability classes gives rise to certain adverse consequences. Indeed, severe erosion in $54 \%$ of the basin takes place in sloping areas devoid of vegetation. Residential waste, intensive use of pesticides-chemical fertilizers, and large industrial facilities pollute dam water and cause land degradation (Pollution levels are higher than that of Class II water).

Interpretation: In order to prevent degrad ation, pollution and siltation of the dam, lands should be used properly and sust a in a ble alternative methods (organic farming, ecological tourism, etc.) should be adopted by locals, particularly the farming industry. An autonomous "Tahtalı Dam Protection Basin Forestry Center" that can ensure interinstitutional cooperation should be created.

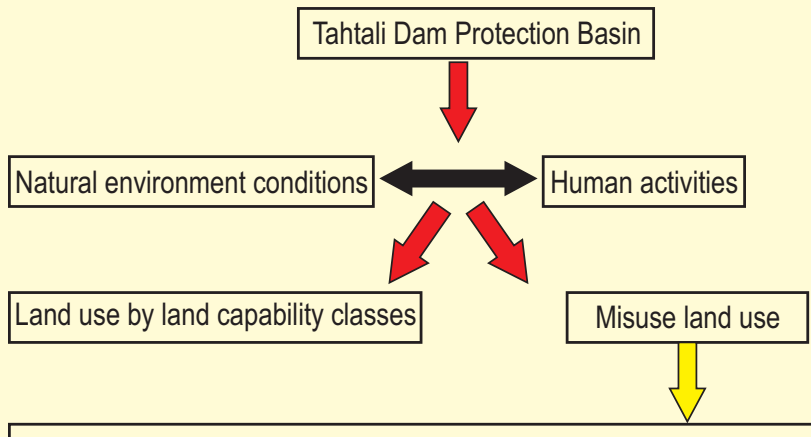

Thirty-one percent of the Tahtali Dam Protection Basin is misused Severe erosion in $54 \%$ of the basin takes place in sloping areas devoid of vegetation Residential waste, intensive use of pesticides-chemical fertilizers, and large industrial facilities pollute dam water and cause land degradation.

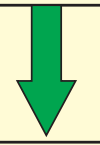

In order to prevent degradation, pollution, and siltation of the dam, lands should be used properly, and sustainable alternative methods 


\section{Introduction}

Growing population, rising demand for resources, and development efforts of developing countries constantly increase the pressure on natural resources (Öztürk, 1999; Öztürk et al., 2002; Atalay and Efe, 2010; Efe et al., 2012; Efe et al., 2013). In Turkey, flat and moderately sloping terrain that is available for agriculture accounts for $21 \%$ (Erinç, 1973), which is why areas such as the Tahtalı Dam Protection Basin, 36\% of which consists of arable flat and moderately sloping lands, are agriculturally and hydrologically crucial for the economy.

Even though dams are largely regarded as environmentfriendly and renewable resources, they lead to shrinkage of agricultural lands, siltation, ecosystem problems, and migration (Tümertekin and Özgüç, 1997; Strahler and Strahler,2006; Sönmez, 2012). Despite the drawbacks, dams are built to meet the demand for drinking-potable water. It is a fact that the economic lives of dams are likely to come to an end in less than 100 years (Strahlerand Strahler, 2006). Preventing siltation and pollution of dams is possible only through engagement of local population in basin protection efforts and employment of a suitable land use method (Ghimire and Pimbert 1997; Berkes 1999; Ay, 2001; Manyari and Carvalho, 2007; Özdemir, 2015).
It is thus wise to assess the relationship between land use and the land classes in the Tahtalı Dam Protection Basin, which meets $34 \%$ of Izmir's water demand, in terms of sustainable use of natural resources. A study that centers on space-human interaction could contribute to basin protection efforts and the creation of an alternative land use pattern.

Study area: The Tahtalı Dam Protection Basin is located in the mid section of the Coastal Aegean Area. The basin is situated between the high areas where the western and southern slopes of Mount Nif $(1510 \mathrm{~m})$ in the northeast link with Buca ridges and Çatalkaya slopes in the west, the Gümüldür-Tahtalı Strait in the south, and the Küçük Menderes's flat terrain. The city of Izmir totally encompasses the basin. Sixty nine per centof the basin is in Menderes; $19 \%$ is located in Buca, and $4.4 \%$ is situated in Gaziemir. Three per cent falls into the Kemalpaşa; $2.4 \%$ is in Torbalı, and $2 \%$ is situated in Karabağlar. Seferihisar contains the remaining $0.2 \%$. The boundaries of the basin encompass the Menderes district center; the Menderes district's Akçaköy, Çatalca, Değirmendere, Dereköy, Develi, Görece, Kısık, Küner, Yeniköy, Oğlananası, Şaşal, Keler, Bulgurca, Tekeli, Sancaklı, Çamönü, Çileme; the Buca district's Karacaağaç, Kırıklar, Belenbaşı, Kaynaklar, Doğancılar; the Torbalı district's Demirci, Yeşilköy, Yoğurtcular, and the Gaziemir district's Sarnıç

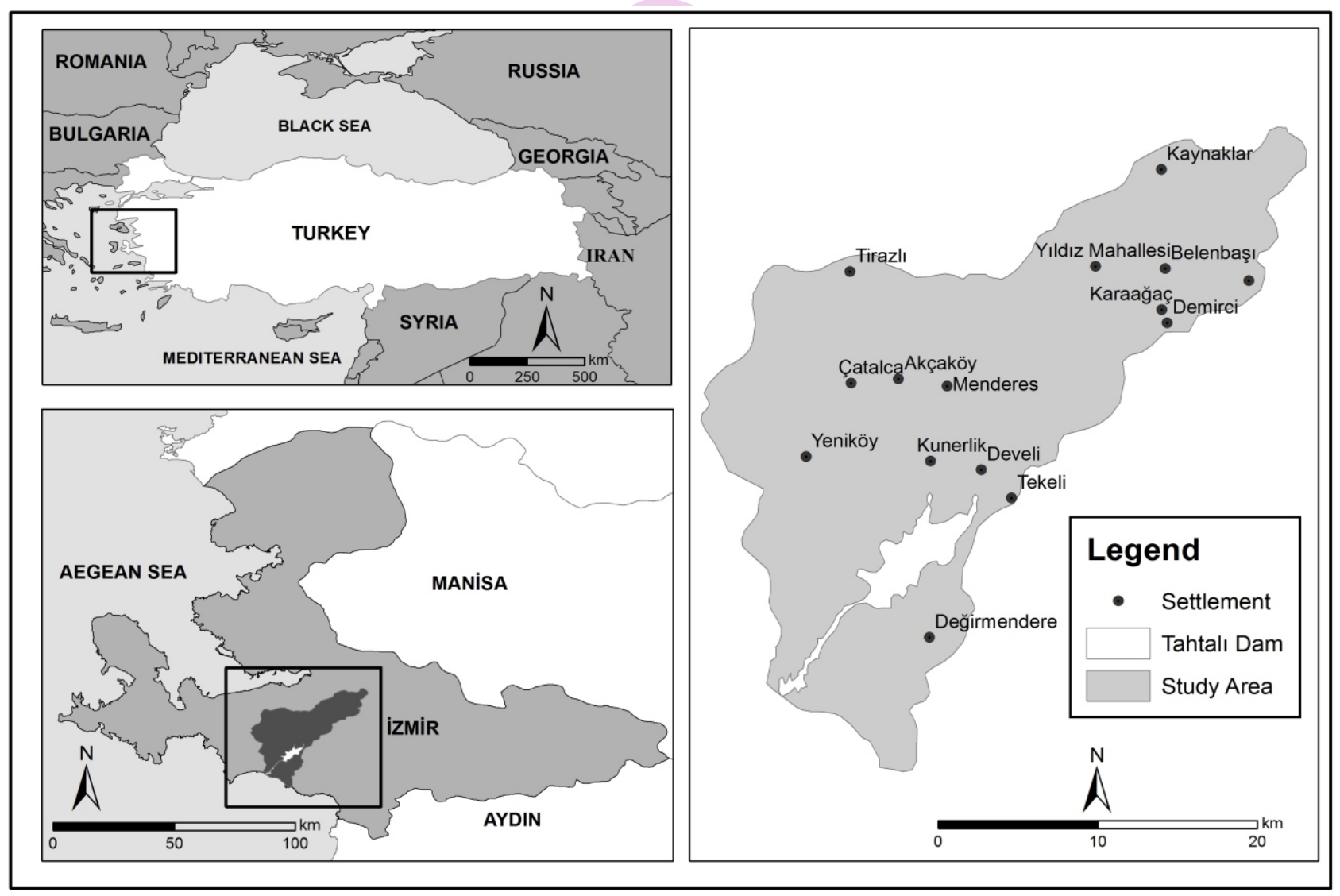

Fig. 1 : Location map of the protection basin of the Tahtalı Dam 


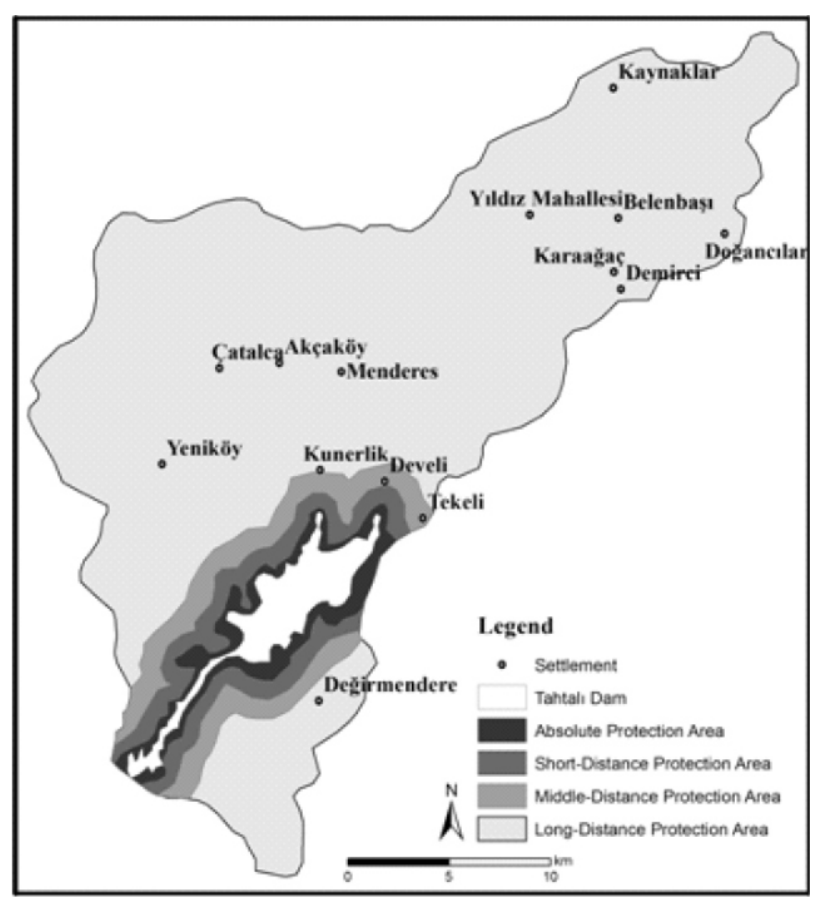

Fig. 2 : Map of the Tahtalı Dam Protection Areas

neighborhood. The basin covers an area of $646 \mathrm{~km}^{2}$ and is drained by the Tahtalı Brook and its tributaries (Fig. 1).

An Environmental Plan with a scale of $1 / 25.000$ was prepared in 1996 (revised in 2002) in order to prevent pollution of the Tahtalı Dam with domestic, agricultural, and animal husbandry-induced waste water, protect public health, and make full use of the natural potential of the water basin. Accordingly, IZSU (İzmir Water and Sewer Authority) issued a regulation regarding the Tahtalı Dam Basin. According to the regulation, beginning from the maximum water level, on a horizontal basis, an area of $0-300 \mathrm{~m}\left(15 \mathrm{~km}^{2}\right)$ was designated as a strict protection area, $300-1000 \mathrm{~m}$ as a short range protection area $\left(28 \mathrm{~km}^{2}\right)$, $1000-2000 \mathrm{~m}$ as a midrange protection area $\left(34 \mathrm{~km}^{2}\right)$, and any area above $2000 \mathrm{~m}$ as a long range protection area $\left(453 \mathrm{~km}^{2}\right)$. The area between $0-100 \mathrm{~m}\left(28 \mathrm{~km}^{2}\right)$ was designated as a stream strict protection area (Fig. 2) (Barış, 2008; IZSU, 2016).

General geographical features of the research area: Alluvium is found on the base of Cumaovası, the TahtalıBrook and its tributaries (Değirmendere, Kocaçay, Kona, Sarıçay, Sandı, and Balaban streams) (Fig. 11), whereas colluvium deposits are present on the edges of plains. Neogene volcanic rocks (rhyolite, tuff, lava, and perlite) are found along a large belt that stretches from the west of the dam to the north of Akçaköy. Lower MiocenePliocene argillaceous limestones are found along the line that lies from the Tekeli Neighborhood in the northeast to the north and also in the large area between Belenbaşı andSarnıç. Neogene loams and sandstones exist as a thin belt among volcanic rocks

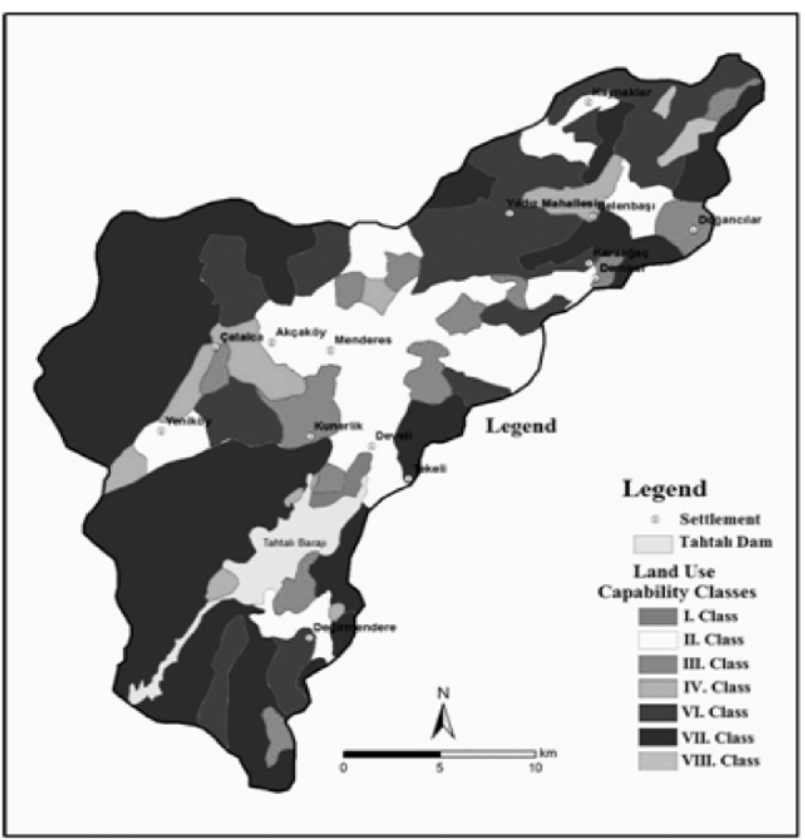

Fig. 3 : The current map of the land capability classes for the Protection of the Tahtalı Dam

and flysch formations in the west of the dam. These sediments are common near the Karacaağaç, Demirci, and Doğancılar districts in the northeast. Neogene limestones, on the other hand, are found as patches in the neighborhoods of Karacaağaç, Doğancılar, and Kaynaklar in the northeast of the area. Mesozoic flysch is located in a narrow area in the west and northeast of the dam (near Kaynaklar), yet it is found along a wide belt in the northwest. Paleozoic marble and schist that underlie the area are found as patches in the south of the dam (YIImaz et al., 2000; Şimşek, 2002; Barış, 2008).

The Cumaovası Basin, a NE-SW Quarternary basin in Western Anatolia, has an approximate width of 5-17 km and a length of $35 \mathrm{~km}$. It is a "pull-apart basin" where asymmetrical, active and potentially active strike-slip and normal faults operate together (Uzel, 2007). The Tahtalı Dam Protection Basin, which encloses the Tahtalı Brook and its tributaries that drain the Cumaovası Basin, can be broken into four main geomorphological units: "basin floor (alluvial areas)", "valleys, flat valley bottoms", "alluvial plains-hills", and "mountainous areas". The highest point in the research area in the dnortheast is the Nifkarlığı Hill (1506 m) while the lowest point is the area near the Tahtalı Dam (10-100 m).

Located in the Mediterranean climate zone, the Tahtalı Dam Protection Basin has an average annual temperature of 17$18^{\circ} \mathrm{C}$, average annual precipitation of $600-700 \mathrm{~mm}$, and average annual relative humidity of $55-70 \%$. Overall, the slopes of the mountains surrounding the basin in the northwest and northeast 
receive copious amounts of precipitation $(750-850 \mathrm{~mm})$ whereas the basin floor gets less than this amount. As the basin stretches largely from north to west, north-south winds are dominant. The dominant wind direction in the basin is mostly $\mathrm{N}$, and average annual wind velocity ranges between 1 and $3.5 \mathrm{~m} / \mathrm{s}$ (Koçman, 1989). So, it is safe to say that the basin has a semi-arid/semihumid climate. Under normal conditions, a dry spell prevails from the first week of June to late October (a water gap of $609 \mathrm{~mm}$ ), which is why the agricultural irrigation date corresponds to this period.

Alluvial soils are common on the basin floor and near the rivers. Colluvial soils dominate the Plio-Quaternary deposits and alluvial cones-fans stretching between Menderes and the Künerlik Neighborhood. The dip slopes of the mountainous areas, which are composed of flysch and volcanic rocks surrounding the basin floor, are full of brown non-calcareous forest soils on which trees, maquis, and garrigues thrive. Higher sections of these mountainous areas feature brown non-calcareous soils. Brown forest soils occur in patchesin Kaynaklar-Demirci and near Belenbaşı in the northeast, in the west of the Yıldız Neighborhood, in the northwest of the dam, and in the south; the west and northeast of Cumaovası contain chestnut soils. The northeast of the basin is home to red Mediterranean soils (terrarossa) occurring on limestones while argillaceous limestones in the Yıldız Neighborhood have rendzina on them (Topraksu, 1974; Koçman, 1989; General Directorate of Rural Services, 2001; Atalay, 2011). Red Mediterranean soils are widespread on Neogene deposits in the northeast, marble in the south, and schist and flysch in the west of Yeniköy.

The Tahtalı Dam Protection Basin is within the Main Mediterranean vegetation belt. Turkish pines (Pinus brutia) and maquis are common in the basin. Turkish pines in the area occupy areas with an altitude of 250-300 $\mathrm{m}$ and 800-900 $\mathrm{m}$ whereas the altitude for maquis ranges from 150-250 to 650-700 m (Koçman, 1989; Günal, 1987). Black pines (Pinus nigra) grow above 900 m; they flourish as part of the Mediterranean-Mountain vegetation belt (the western slopes of Mount Nif and eastern slopes of Mount Tekke) (Günal, 1987; Çukur, 1998, Atalay, 2002; Atalay, 2008). Volcanic sands in the vicinity of Künerköy are home to stone pines (Pinus pinea) (Çukur, 1998). Forests near settlements are largely degraded, have turned into maquis or agricultural lands, and surfaces without vegetation are visible (Özturk, 1995, 1999; Feoli et al., 2003).

The research area is relatively rich in ground-surface water. The basin is drained by Tahtalı (Dereboğaz) Stream that emerges with the confluence of the Bulgurca (Kona, Kocaçay, Tahtalıçay, Değirmendere and Sarıçay streams) and Kocaçay (Sandı and Balaban streams) streams. The construction of the Tahtalı Dam across the Tahtalı Streamcausedthe Hırsız, Deliömerand İzmirliboğazı streamstofeed into the dam alongside Bulgurca and Kocaçay. The Tahtalı Dam, constructed by the
General Directorate of State Hydraulic Works (DSi) between 1986 and 1996, is the most important drinking and potable water resource of İzmir and accounts for 34\% of the city's water demand. The dam was handed over to IZSU in 1997, and water provision to Izmir began that year. It is located $40 \mathrm{~km}$ south of the metropolitan area of İzmir, and $5 \mathrm{~km}$ east of the Gümüldür Neighborhood (Fig. 12). One hundred fifty threemillion $\mathrm{m}^{3}$ of water annually reaches the Tahtalı Dam from a precipitation basin of $646 \mathrm{~km}^{2}$, and 128 million $\mathrm{m}^{3}$ of water can be drawn. The minimum water level of the dam is $31 \mathrm{~m}$, and the dam stands at a height of $61 \mathrm{~m}$. The Tahtalı Dam covers an area of approximately $25 \mathrm{~km}^{2}$. Whereas the volume at the minimum water level amounts to 19.6 million $\mathrm{m}^{3}$, the volume at the maximum water level equals 306.7 million $\mathrm{m}^{3}$ (IZSU, 2016). Built mainly for the purpose of providing drinking-potable water, the dam has an irrigation area of 1000 ha. There are two aquifer systems in the basin: alluvium and limestones that form an unconfined aquifer in terms of groundwater and conglomerates that create a semi-confined aquifer. Alluvial and Neogene argillaceous limestones provide a considerable amount of drinking and irrigation water in the midsections of the basin. Forty-five per centof precipitation that falls on the basin is spent through evaporation-perspiration; $39 \%$ flows into the Tahtalı Dam Basin by joining the surface flow, and the remaining $16 \%$ feeds groundwater, which locals draw mostly fromshallow wells. The number of privately owned wells registered to DSI equals 120 as of 2005. If the wells owned by irrigation cooperatives and unregistered wells are taken into account, the number goes over 500 . The difference between the inflow and outflow of the basin amounts to $-35 \times 106 \mathrm{~m}^{3}$. In other words, over 35 million $\mathrm{m}^{3}$ is drawn without this amount being compensated for by the inflow, which signals that water drawing exceeds the allowed amount. In addition, there is a $5.62 \mathrm{~m}$ difference between the static level measurements in the rainy and dry spells. For this reason, most of the caisson wells in the basin are abandoned in summer while drilling wells are deepened or left unused. Water of the basin is rated as "very good-good" and "good-usable" (C2-S1 and C3-S1) for irrigation (Barış, 2008). The basin is also home to ponds that have been created for provision of irrigation and drinking water (the Balaban and Sandı ponds).

Since the Late Chalcolithic (Copper) Age $\left(4^{\text {th }}-3^{\text {rd }}\right.$ millennium BCE), the Tahtalı Dam Protection Basin has been settled (Bakla, the Altıntepe Mound, and Colophon) (Tuğcu, 2004). As of $2015,94.649$ people live in the basin, of whom $38 \%$ reside in the district center of Menderes, and $62 \%$ dwell in the neighborhoods that are no longer villages according to the "Metropolitan Law". The important settlement areas in the basin include the Menderes district center (35.540), Sarnıç (25.427), Görece (7590), Tekeli (2823), Küner (2227), Develi (1994), Bulgurca (1821), Çileme (1790), Oğlananası (1782), Çamönü (1695 people), Değirmendere (1589), Kırıklar (1520) and Kaynaklar (1248) (TÜIK, 2015). Menderes is a developed area in terms of commerce, agriculture, and transportation and is the 
most important settlement area in the basin. The smallest settlement unit is the Keler Neighborhood with its 179 inhabitants; $40 \%$ of its settlement area and $70 \%$ of its land has been submerged by the Tahtalı Dam. Another point to consider is migration to basin settlements, in particular to the neighborhoods in the Menderes and Buca districts. Migration is mostly driven by the opportunities Izmir offers, and it should be closely monitored and controlled with regard to the basin protection status.

Agriculture constitutes the bulk of the economic profile of the basin $(60 \%)$ followed by commerce, industry, and transportation. Wheat, olive, corn, vegetable, fruit, and grape production - in order - are the dominant agricultural elements as of 2015 (TÜBITAK-MAM, 2010; Buca, Gaziemir, Menderes, Torbalı districtAgriculture directorates, 2015).

\section{Materials and Methods}

This study draws on a Landsat OLI satellite image with 15 $\mathrm{m}$ spatial resolution; it was obtained through remote sensing and is frequently employed in studies on land use. The Lands at OLI satellite image from 2015 was subjected to controlled classification in Erdas Imagine software. Classified with the use of the "maximum likelihood method", the image was first composed of 150 classes. Later on, already recoded images were reduced to five classes, and a map showing current (2015) land use of the Tahtalı Dam Protection Basin was created. The accuracy rate of the map equals 0.85 according to Cohen's kappa coefficient. The map of the land capability classes was prepared through the integration of land observations, the İzmir Land Size maps drawn by the General Directorate of Rural Services, and so on. The study intends to shed light on current land use by using land observations, photographs, and maps. The relationship between

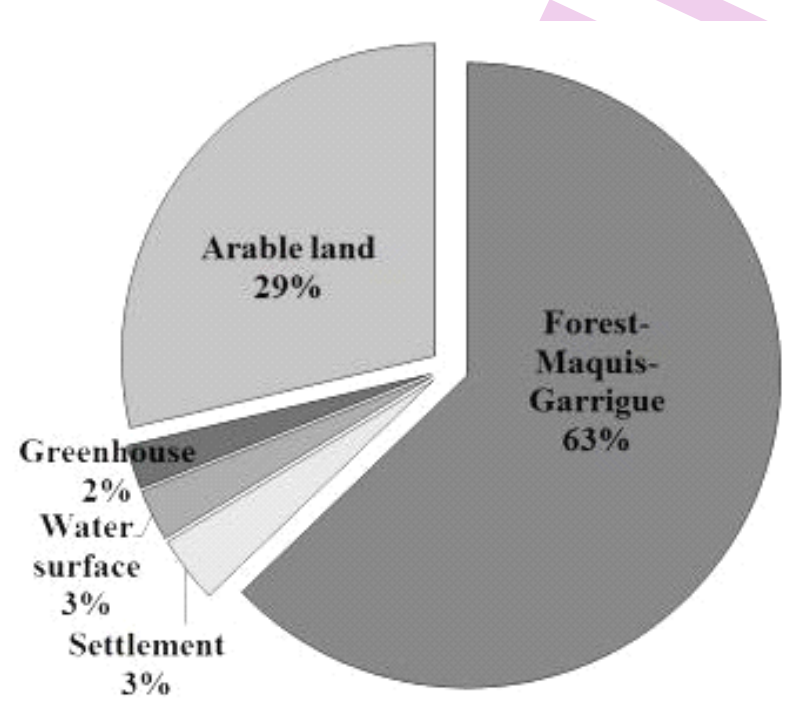

the land classes and land use types wassubjected to overlay analysis on Arcgis 10.x, and geography-related suggestions were offered based on the results obtained. Land observations were made in order for relationships between types of land use and land capability classes in the basin to be able to determine as well as these.

\section{Results and Discussion}

This chapter will focus mainly on the findings of this research. First, the land capability classes that demonstrate the natural potential of the basin will be specified, and useful information on current land use will be provided.

Land capability classes: The land capability classes are about the ideal use of nature's potential (Burley, 1961; Andersonet al., 1972; Gülersoy, 2001 and 2008; Gülersoyet al., 2015; GülersoyandÇelik, 2015; Atalay and Gündüzoğlu, 2015). The "U.S Soil Conservation Service" developed the land capability classification system, which lists 8 classes of land capability (Hockensmith and Steele, 1943; Kellogg, 1951; General Directorate of Rural Services, 2001; Panhalkar, 2011). Scientists are still improving land classification systems (Eswaran et al., 2000). Agriculturally important Class I, Iland IIIlands occur on the basin floor and make up 30\% of the entire area (Fig. 16, 17and 19). These lands are largely used as fields and greenhouse areas $(53 \%$, Fig. 13), yet it is significant that a substantial portion is covered with forests $(24 \%)$ and water surfaces (17\%). Class IV lands mostly occupy colluvial deposits (Plio-Quaternary deposits and alluvial cones-fans) and constitute $6 \%$ of the area. These lands are mostly covered with forests (68\%); they are used as olive groves, dry or irrigated farming areas, and greenhouse areas (31\%). For Class $\mathrm{V}$ lands covered a very small place in the

Fig. 4 : Current land capability classes and land use case of the Protection Basin of the Tahtalı Dam (\%) 


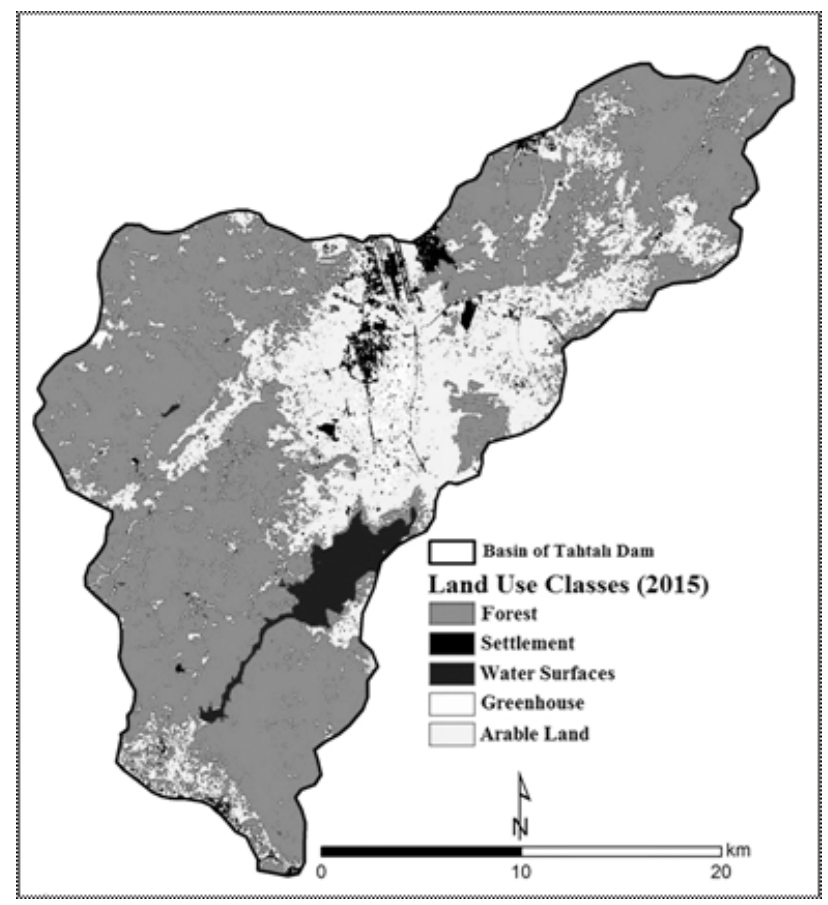

Fig. 5 : The map of current land use for the Protection Basin of the Tahtalı Dam

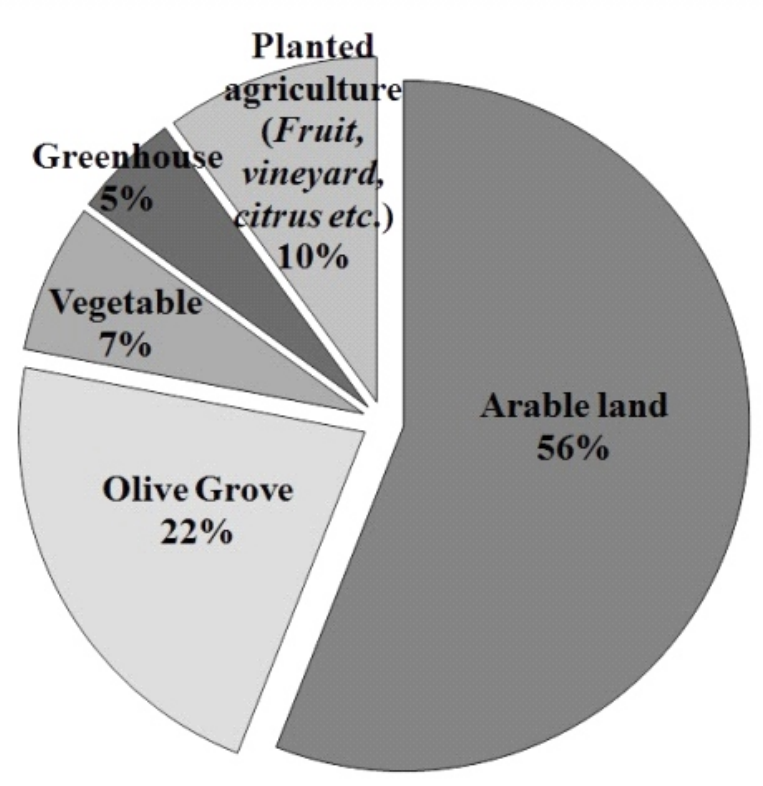

Fig. 6 : Agricultural land use case of the Protection Basin of the Tahtalı Dam in 2015 (\%)

basin, they were not taken into consideration. Class VI lands add up to $21 \%$ of the basin and are located largely beneath the forest cover $(75 \%)$. A considerable chunk $(22 \%)$ is used as fields and greenhouse areas. Class VI lands, which are supposed to be utilized as pastures, are used for grazing, which is why they are being degraded (Fig. 14). Class VII lands account for $42 \%$ of the area and occur largely on flysch, metamorphic rocks, limestones, and volcanic rocks. These lands are under the forest cover to a great extent (82\%). Agricultural activities take place on $16 \%$, which is very problematic. Class VIII lands make up merely $1 \%$ of the basin and are composed of stony, rocky, and sandy areas (Fig. 3 and 4).

Land use: Today, forests-maquis-garrigues make up a considerable portion (62.8\%) of the entire area of the Tahtalı Dam Protection Basin while agricultural areas constitute the rest $(31 \%)$. Settlement areas in the basin, which is located in the hinterland of Izmir, cover a larger area (3.5\%) compared to other similar locations (1\%) in Turkey. Water surfaces make up $2.7 \%$ of the basin because of the Tahtalı Dam (Fig. 4 and 5).

As the dam gathered water, IZSU issued the "Tahtalı Dam Agricultural Notice" in 1997, which allowed dry and ecological farming in nearby protection areas without the use of artificial fertilizers and pesticides. Animal husbandry, on the other hand, was not permitted. In the midrange protection areas, vegetable, vineyard, and fruit farming is carried out without artificial fertilizers and pesticides. Vegetables are cultivated without water; vineyard and fruit farming is carried out either without water or with the use of drip irrigation. Greenhouse owners are required to engage in soilless agriculture and gather waste water in a leak-proof cesspit and move it away from the basin. In the long range protection area, the use of pesticides with Atrazine, Aldicarb, Alachlor, Benomyl, Carbofuran, Chlorsulfuran, Diquat, Endosulfane, Ethion, Fenamiphos, Linuran, Maneb, Mancozeb, Methylbromide, Monochrotophos, Paraquat, Propicanozole, Simazine, Triphenyltin hydroxide, and Trifluralin is not permitted, and the need for fertilizers is determined according to soil analyses. Agriculture is allowed only if these conditions are met (IZSU, 1997). Such conditions led to an increase in dry farming and greenhouse activities in the basin (Fig. 13).

Fifty six per cent of agricultural lands are allocated to dry farming ( $48 \%$ grains (wheat, barley), $43 \%$ to olive groves, vineyards, and fruit zones, $6 \%$ to other products, and $3 \%$ to tobacco) (Fig. 6, 10and 13). The protection status of the study area brought dry farming activities (grains and olive in particular) and greenhousing (organic farming) into prominence. Dry farming lands stretch almost all across the land and are on Class I (1\%), Class II (38\%), Class III (17\%), and Class IV (6\%) lands. Dry farming activities on Class VII (22\%) and Class VI (15\%) lands in the basin are worth the attention(Fig. 17). Dry farming is mostly practiced in the north and northeast of the dam, on Neogene plains, alluvial and colluvial deposits, and flysch. Dry farming is used commonly in Görece, Doğancılar, Akçaköy, Şaşal, Küner, Bulgurca, Kısık, Kırıklar, Yeşilköy, Sancaklı, Menderes, Yoğurtçular, Yeniköy and Develi (Buca, Gaziemir, Menderes, Torbalı districtAgriculture directorates, 2015). 


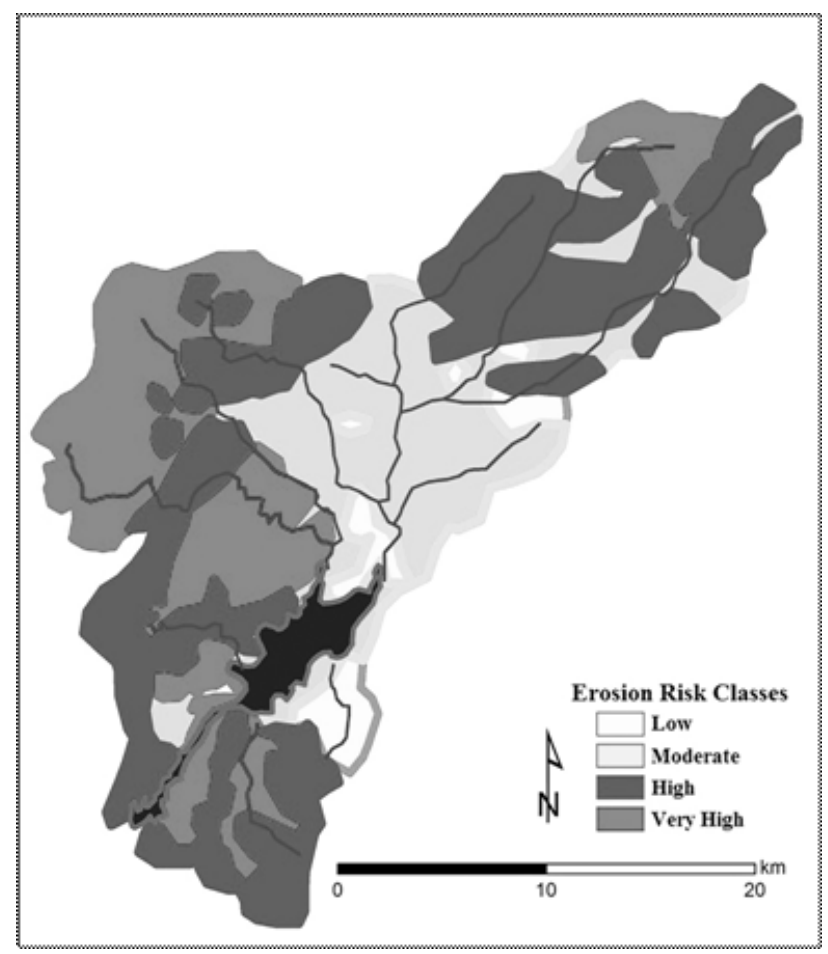

Fig. 7 : The erosion map of the Protection Basin of the Tahtalı Dam

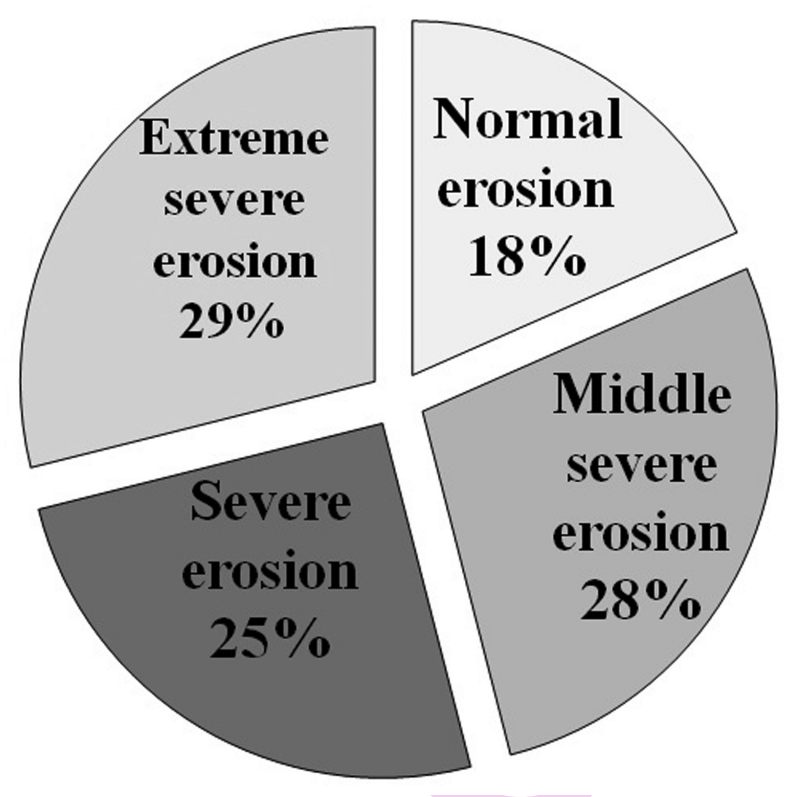

Fig. 8 : Erosion classes in the Protection Basin of the Tahtalı Dam (\%)

Although dry farming is generally encouraged as part of basin protection efforts, irrigated farming lands occupy large areas (44\%). Greenhousing and irrigated farming, which are intensely practiced on Class I (1\%), Class II (72\%), Class III (6\%), and Class IV (4\%) lands, are concentrated on the floor basin and in valleys. Irrigated farming on Class VII (17\%) and Class VI (4\%) lands is very problematic (Fig. 5, 6, 13 and 18). Irrigated farming in the protection basin hinges on groundwater. Sixteen per cent of precipitation that falls on the basin feeds groundwater and is extracted from over 500 wells. Well water levels drop each year, as a result of overuse which they are deepened or abandoned. Irrigated farming is crucial in Çamönü, Karacaağaç, Çileme, Sarnıç, Tekeli, Oğlananası, Kaynaklar, Değirmendere, Belenbaşı and Demirci. Olive groves $(6 \%$ of the basin and $22 \%$ of agricultural lands) are widespread on Neogene sediments, colluvial deposits, and flysch. Olive production is important in Bulgurca, Doğancılar, Belenbaşı, Kaynaklar, Akçaköy, Değirmendere, Sancakı, Şaşal, Çatalca, Menderes, Kırıklar and Karacaağaç (Buca, Gaziemir, Menderes, Torbalı district Agriculture directorates, 2015). Nevertheless, it is possible to encounter maquis and olive groves in degraded forests.

Data 2015 (Fig. 6) on the use of agricultural lands in the Tahtalı Dam Protection Basin lists farmlands as the largest $(56 \%)$, followed by olive groves $(22 \%)$, planted areas $(10 \%)$, vegetable areas $(7 \%)$, and greenhouses $(5 \%)$. Wheat, barley $(26 \%)$, corn $(11 \%)$, tobacco $(2 \%)$, cotton $(1 \%)$, and forage plants such as vetch and alfalfa (5\%) are cultivated in farmlands. Sarnıç, Kısık, Görece, Şaşal, Küner, Oğlananası, Menderes, Develi, Çatalca, and Yeniköy are the regions with significant wheat and barley production. Çileme, Tekeli, Sancaklı, Oğlananası, Develi, and Çamönü are the leading regions in corn production. Yeşilköy, Demirci, Yoğurtçular, Tekeli, Sancaklı, and Çileme are at the forefront of tobacco production while Çileme, Tekeli, Oğlananası, and Develi produce significant amounts of cotton. Planted areas are used for fruit and citrus cultivation and vineyards (Buca, Gaziemir, Menderes, Torbalı district Agriculture directorates, 2015). Grape, plum, cherry, pear, apricot, fig, pomegranate, almond, peach, and pistachio production has long been crucial for the basin, and production areas of these plants have regularly expanded. Fruit cultivation in the upper sections of the basin has gained pace in the last few years as a result of incentives for organic farming. Indeed, Yoğurtçular, Belenbaşı, Kaynaklar, Demirci, Kırıklar, Karacaağaç, Yeşilköy, and Doğancılar are settlements with considerable fruit output (Fig. 10). Vineyards also expand rapidly in the basin where economic activities have been restricted lately due to the protection status (Fig. 17). In fact, land observations revealed recently established vineyards on Neogene sediments and volcanic rocks in the north of the basin (the Yeniköy and Çatalca neighborhoods). Yeniköy, Görece, Çatalca, and Akçaköy are home to vast vineyards. Yeşilköy, Demirci, Çamönü, Yoğurtçular, Karacaağaç, and Tekeli provide significant vegetable output. The research area is vital in watermelon, pepper, tomato, artichoke, and melon production.

Protection efforts in the basin - short, mid, and long range protection areas in particular - have led to an increase in number of green houses along with a rise in dry farming. For instance, the 


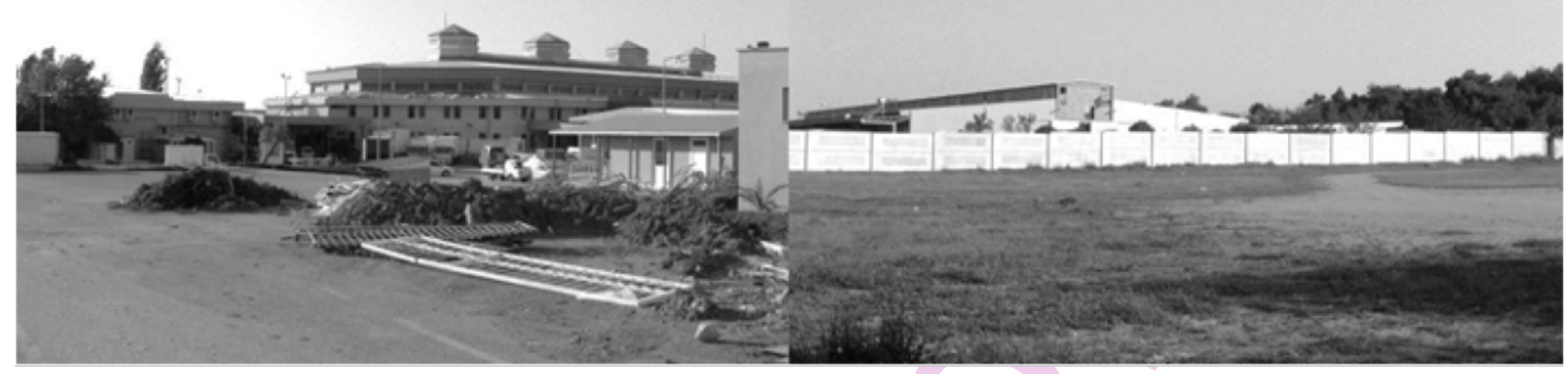

Fig. 9 : The Kaynaklar Fish Market (left) and the Kaynaklar Vegetable Market (right) located in the long range protection area transport pollutants to the Tahtalı Dam, a strict protection area, through the streams

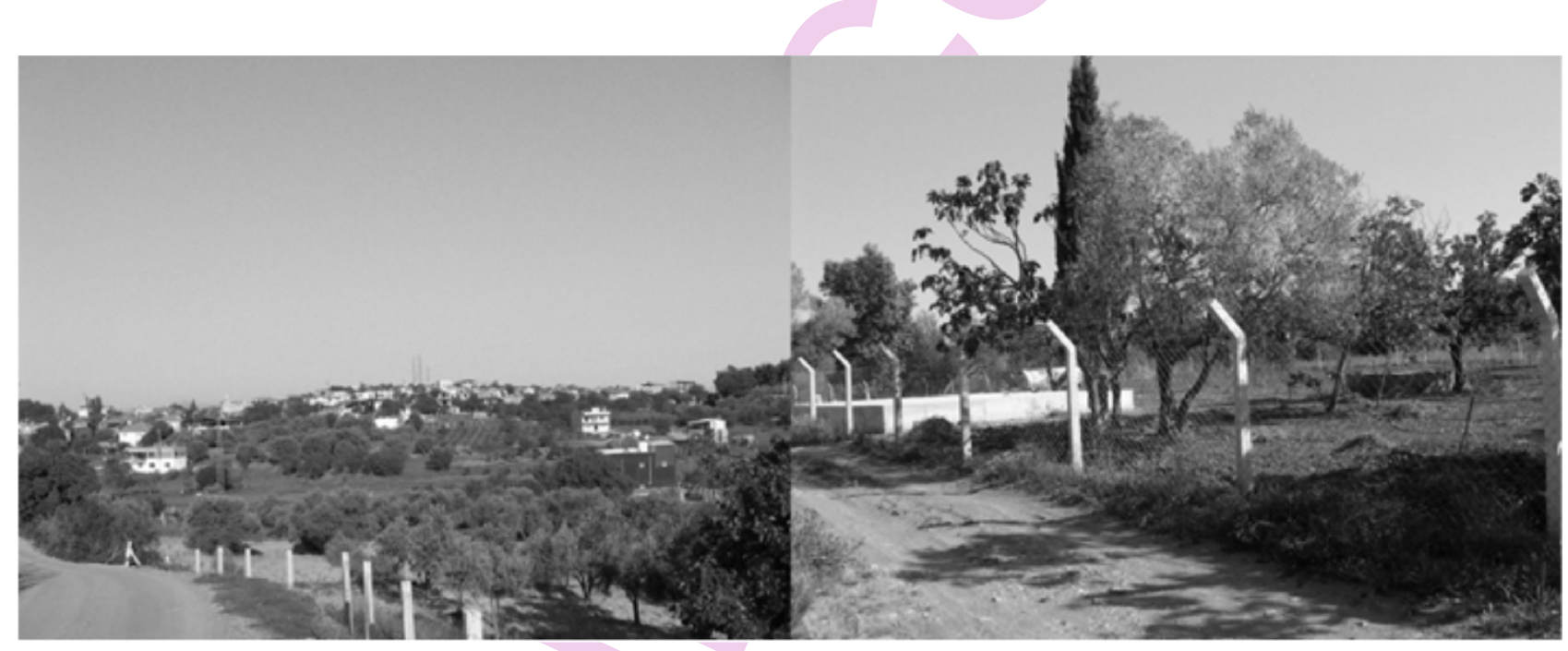

Fig. 10 : Planting and organic farming have become popular due to protection efforts in the research area. Planted areas in the Belenbaşı Neighborhood on the left, planted areas in the Karaağaç Neighborhood on the right

period between 1996 and 2000 saw a decline in olive (17\%), tobacco $(7 \%)$, vegetable $(158 \%)$ and fruit $(21 \%)$ growth areas while there was a $25 \%$ increase in grain areas, $14 \%$ in cotton areas, $38 \%$ in vineyards, and $64 \%$ in greenhouses (Tüzel et al., 2002). Greenhouses, which make up $5 \%\left(8.2 \mathrm{~km}^{2}\right)$ of agricultural lands in the basin, are usually used to grow cucumbers, lettuce, rucola, parsley, tomatoes, beans, portulaca, and cress. Cloves and roses are important plants in terms of cut flower production (Fig. 5, 6and 13). Six percent of the greenhouses in the basin are made of glass, $75 \%$ of plastic, and $19 \%$ of other materials (Selçuk and Elçi, 2008). The number of villages and families cultivating vegetables and fruits equals 20 and 1652 , respectively. The number of villages and families growing outdoor plants is 3 and 380, respectively. Çamönü, Menderes, Sancaklı, Develi, Değirmendere, Küner, Çileme, Tekeli, and
Belenbaşı are the settlements where there are large numbers of greenhouses.

Forests (62.8\%) occur in mountainous-hilly areas that are on Class VI and VII lands (10-15\% slope) with heavy presence of metamorphic rocks (marble and schist), flysch, limestones, marn, and volcanic rocks (Fig. 5 and 15). The research area mainly falls into the Mediterranean Zonobiome, and north and west-facing slopes of mountainous areas harbor eligible humidity conditions for widespread Turkish pine (Pinus brutia) distribution. Turkish pines occur at 250-300 and above, reaching 800-900 meters in mountainous-hilly areas. These trees mingle with maquis, oaks, and hygrophilous species inside valleys (Fig. 15). In general, Turkish pines with skewed trunks grow on sandy soils that occur due to decomposition of metamorphic rocks (excluding 


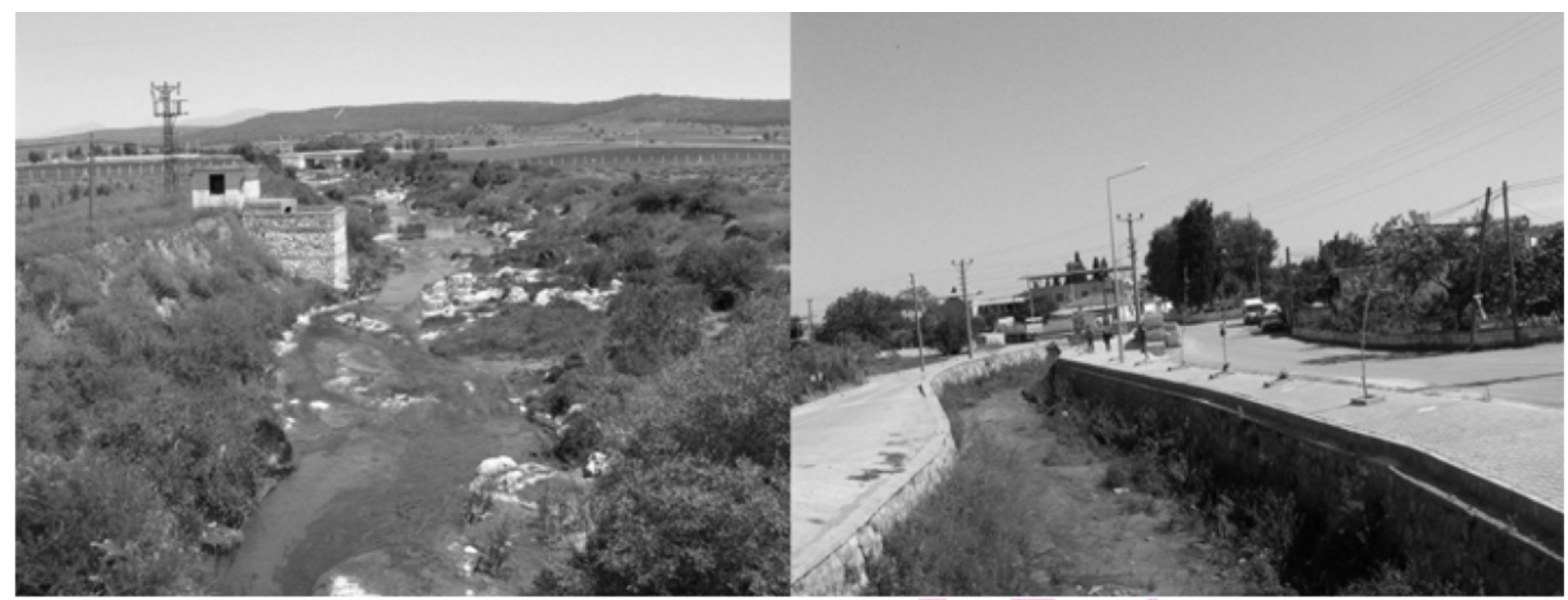

Fig. 11 : Settlements on the basin floor - Menderes district center in particular - dump their sewage and industrial waste into Sarıçay, which pollutes the Tahtalı Dam (pay attention to weeds). Sewage that is dumped from sewage trucks into the streams must be investigated and subjected to legal proceedings. Besides, the İzmir Metropolitan Municipality should be quick to establish recycling and treatment facilities that can process waste from any settlement in the basin

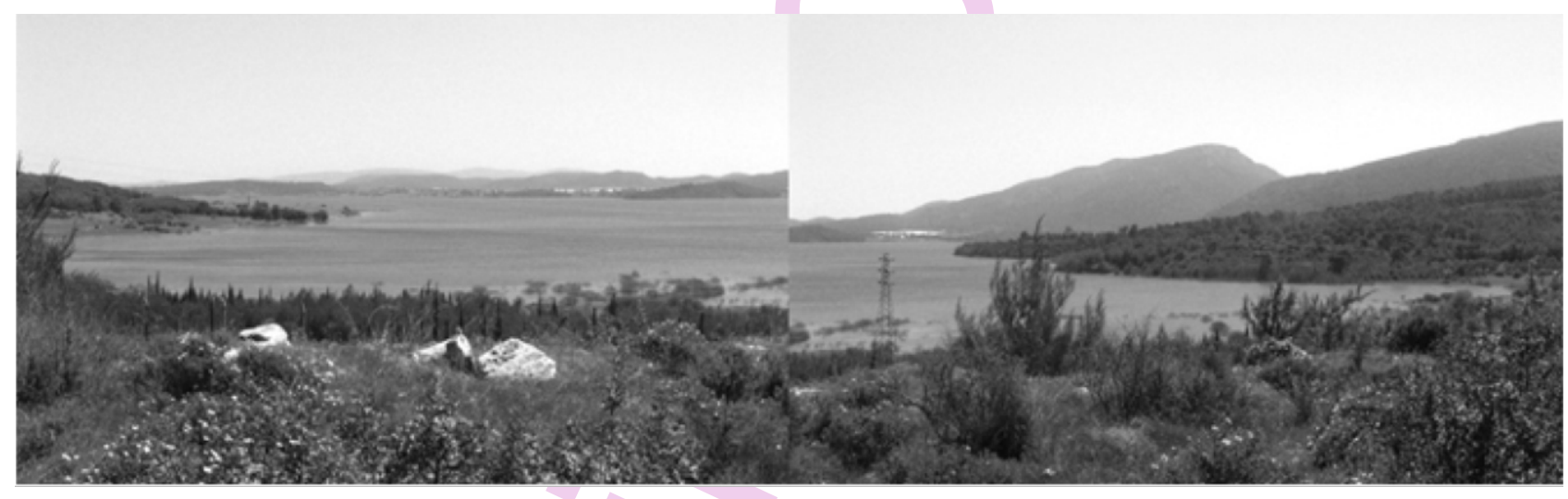

Fig. 12 : An overview of the submerged Bulgurca Village and Tahtalı Dam from the west of the Çileme Neighborhood

conditions such as slopes and hydrology, etc.) while Turkish pines with proper trunks thrive on flysch, limestones, and Neogene sediments. Maquis species under Turkish pines are sparse and thin.Turkish pine trees near settlement areas have been largely degraded, and bare lands devoid of vegetation are encountered in these areas where forests turn into swathes of maquisgarrigues or farmlands (Çukur, 1998). Turkish pines are found in Mount Tekke $(1017 \mathrm{~m})$ in the northwest of the basin that is unaffected by humans. They also grow at 1000-1100 meters on the western slopes of Mount Nif (1446 m) in the northeast. Stone pines (Pinus pinea) thrive on volcanic sands near Künerköy (Çukur, 1998). Black pines (Pinus nigra), on the other hand, grow at $850-900 \mathrm{~m}$ on the western slopes of Mount Nif and eastern slopes of Mount Tekke and can be seen in locations as high as mountain steppes. Forests in the Tahtalı Dam Protection Basin are mostly on Class VII (55\%) and VI (25\%) lands.

Patches of maquis-garrigues (30\%), which are the results of degradation, can be encountered inside forests (Fig.5 and 15).
Maquis-garrigues mostly appear at 150-250 meters and can reach 650-700 meters. In slightly high hills to the northeast of Menderes and in other sections of the basin, ryegrass, sandalwood trees, terebinth, kermes oaks, phllyrea, prickly junipers, strawberry trees, pink rock roses, sage, and leaved rock roses can thrive up to 500 meters of elevation (Koçman, 1989; Günal, 1987). Olive groves have been created at elevations up to $450-500 \mathrm{~m}$ by planting saplings and vaccinating ryegrass mainly on Neogene plains. Hygrophilous maquis species such as laurel, myrtus, and nerium can be found in valleys upan elevation of 700$800 \mathrm{~m}$. However, xerophytic maquis species are more common on the south-facing slopes. Oak species (Quercus ithaburensis, Q. cerris, Q. pubescens and Q. infectoria) join Turkish pines near Mount Tekke (1017 m) and Karacadağ (770 m), and the lower layers are populated by trees. On volcanic rocks (andesite and basalt) with low water holding capacities and on Mesozoic limestones with shallow soils, these forests are replaced by garrigues. On Cretaceous limestones and flysch, maquis species 


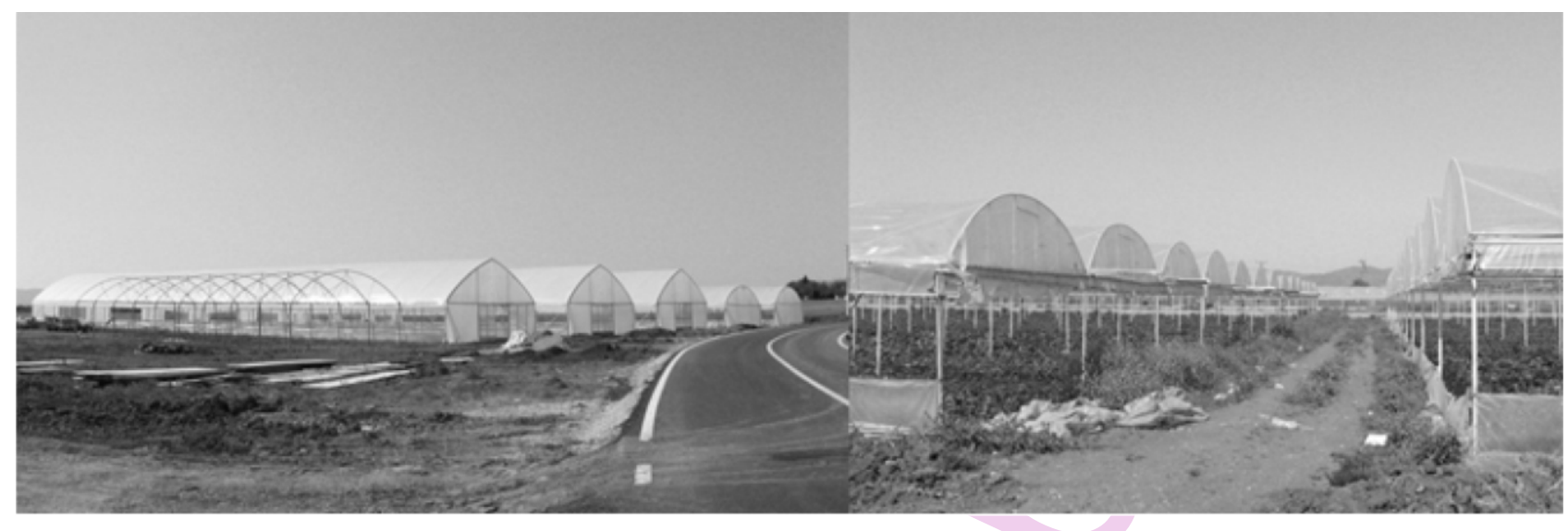

Fig. 13 : Greenhousing is widely practiced in the basin. An image of greenhouses between the Oğlananası and Bulgurca neighborhoods on the left and an image of greenhouses between Tekeli and Çileme on the right

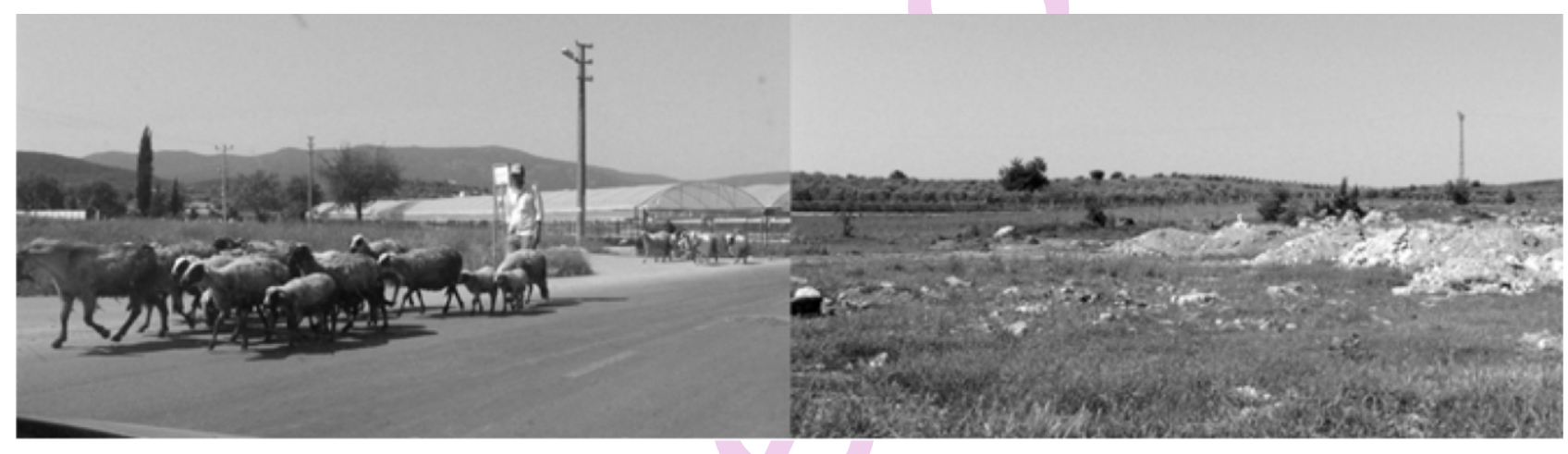

Fig. 14 : Despite protection efforts, ovine breeding is still practiced. Ovine animals grazing near Çileme on the left and ovine animals grazing near the Yeni Bulgurca Neighborhood on the right

are dominant. Above 300-400 m on the north-facing slopes, there are Aleppo oaks (Quercus infectoria), terebinth (Pistacia terebinthus), weaver's broom (Spartium junceum), and kermes oaks (Quercus coccifera) (Günal, 1987). Along the river beds in the basin, it is possible to find nerium (Nerium oleander), vitex (Vitex agnus-castus), sallows (Salix), tamarisks (Tamarix), Aeropyrum (Aeropyrum), and Cockleburs (Xanthium) (Günal, 1987). High mountain plants and meadows occupy the area near the Nifkarlığı Hill (1506 m) (Koçman, 1989).

Another important issue is the afforestation efforts in the Tahtalı Dam Strict Protection Area that went underway in 2001. As part of these efforts, stone pines (Pinus pinea), Turkish pines (Pinus brutia), coojong (Acacia cyanophylla), black locust (Robinia pseudoacacia), iron tree (Casuarina equistifolia), cork oak (Quercus suber), valonia oak (Quercus ithaburensis subsp. macrolepis), mastic (Pistacia lentiscus), Styrax officinalis, tree of heaven (Ailanthus altissima), Mediterranean cypress (Cupressus sempervirens), and Arizona cypress (Cupressus arizonica) saplings were planted (IZSU, 2016). An interesting fact is that Class VII lands, which are supposed to be covered with forests, contain maquis and garrigues, which points to the level of land degradation in the basin (Fig. 15).

The protection status of the research area - short and midrange protection areas in particular - limit animal husbandry, which is why the land use pattern does not regard pastures as a distinct land use type. In fact, the ratio of pastures $(1.7 \%$ of the basin) in the settlement areas to the total area does not exceed $2 \%$. Animal husbandry that is practiced despite protection efforts aggravate the level of degradation. Early and overgrazing in areas with over $10 \%$ slope, which are supposed to be covered with firm vegetation, intensify erosion. In general, a cattle needs 5 hectares (at least 3 ha) of pasture while a sheep or goat needs 1.3 ha (Doğanay, 1995). In Turkey, however, a bovine animal gets 1.6 hectares, and an ovine animal gets 0.5 hectares of pasture. In the Tahtalı Dam Protection Basin, a bovine animal gets 0.03 ha of pasture while an ovine animal gets 0.02 ha. As such, there is a mismatch between pastures and the current animal number. Lack of pastures causes maquis and olive groves to be used as grasslands, which accelerates land degradation (Fig. 14). Stockyards and goats eating saplings were detected during land 


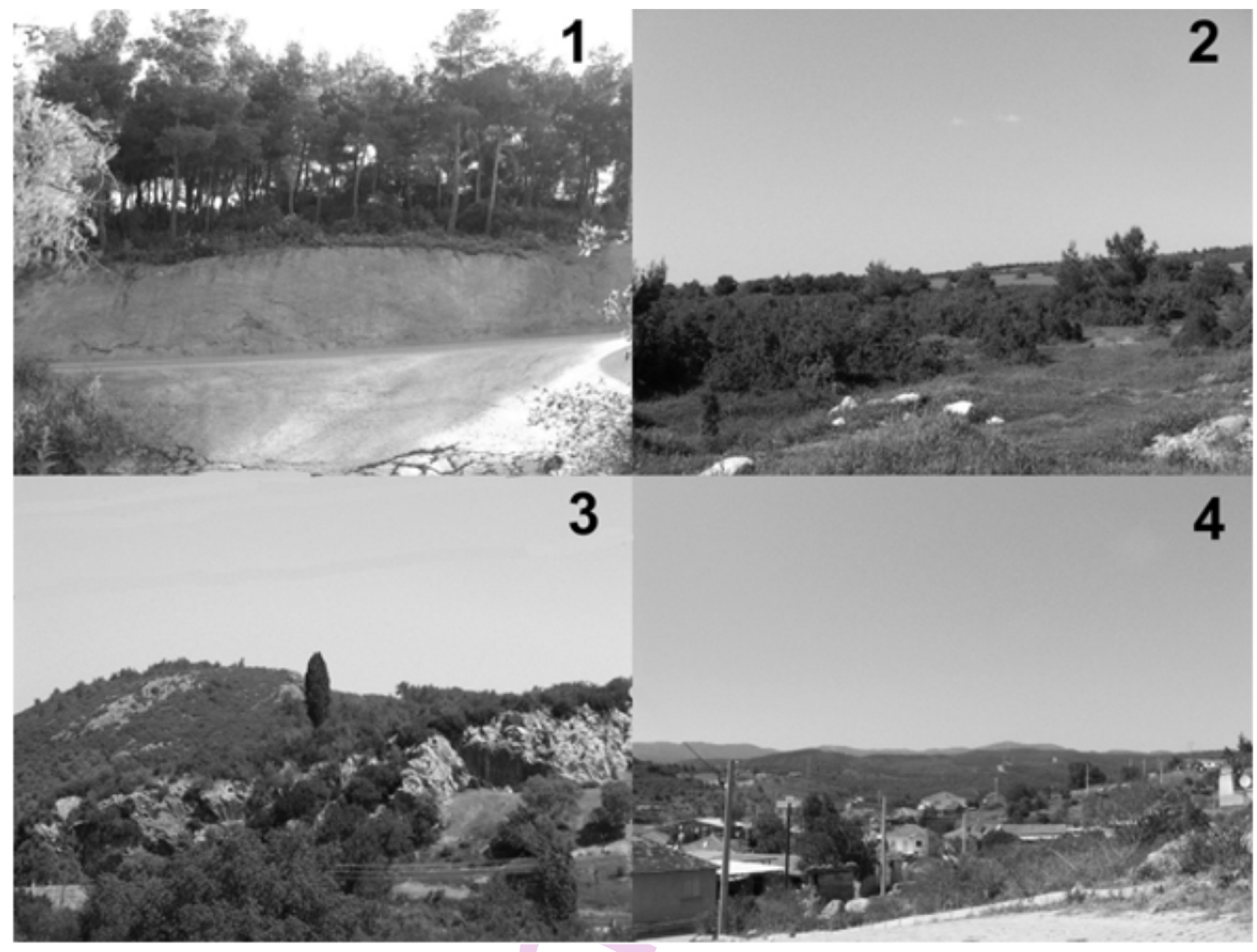

Fig. 15 : Sloping, rugged, and high areas in the basin are covered with forests-maquis-garrigues (1-south of the Belenbaşı Neighborhood, 2-west of the Bulgurca Neighborhood, 3-north of the Değirmendere Neighborhood, 4-west of the Akçaköy Neighborhood)

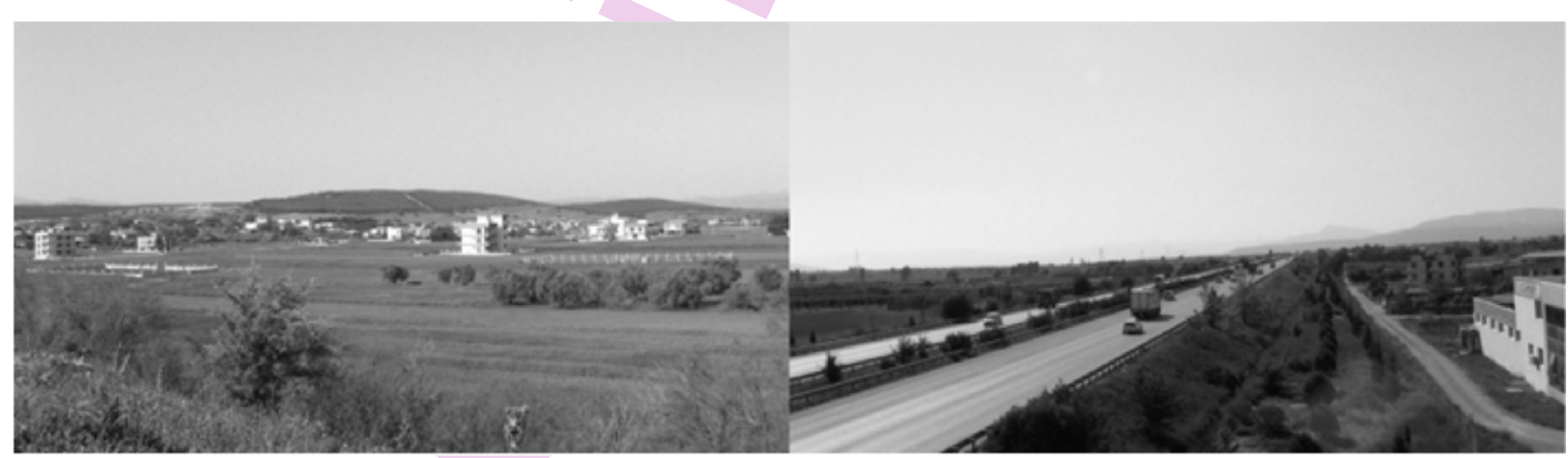

Fig. 16 : Striking examples of misuse of lands on the basin floor. Left: Settlements in the Oğlananası Neighborhood tend to expand from alluvial plains to the plain. Right: The İzmir-Aydın Highway runs along the basin floor, which is an example of land misuse

observations. Corn, barley, vetch, alfalfa, and oat are cultivated in the basin. One per cent of the basin is made up of stony, rocky, and sandy areas, roads, and degraded lands (Fig. 3, 4 and 5). Class VII lands (42\%), which are supposed to be under the forest cover, and Class VI lands (21\%), which are supposed to be used as grasslands, are partly devoid of vegetation (Fig. 5, 7, and 8).

Three and half per cent of the basin is allocated to settlement, commerce, industry, tourism, and mining (Fig. 4, 5 and 9). Settlement areas are on Class II (52\%), Class VI (20\%), 


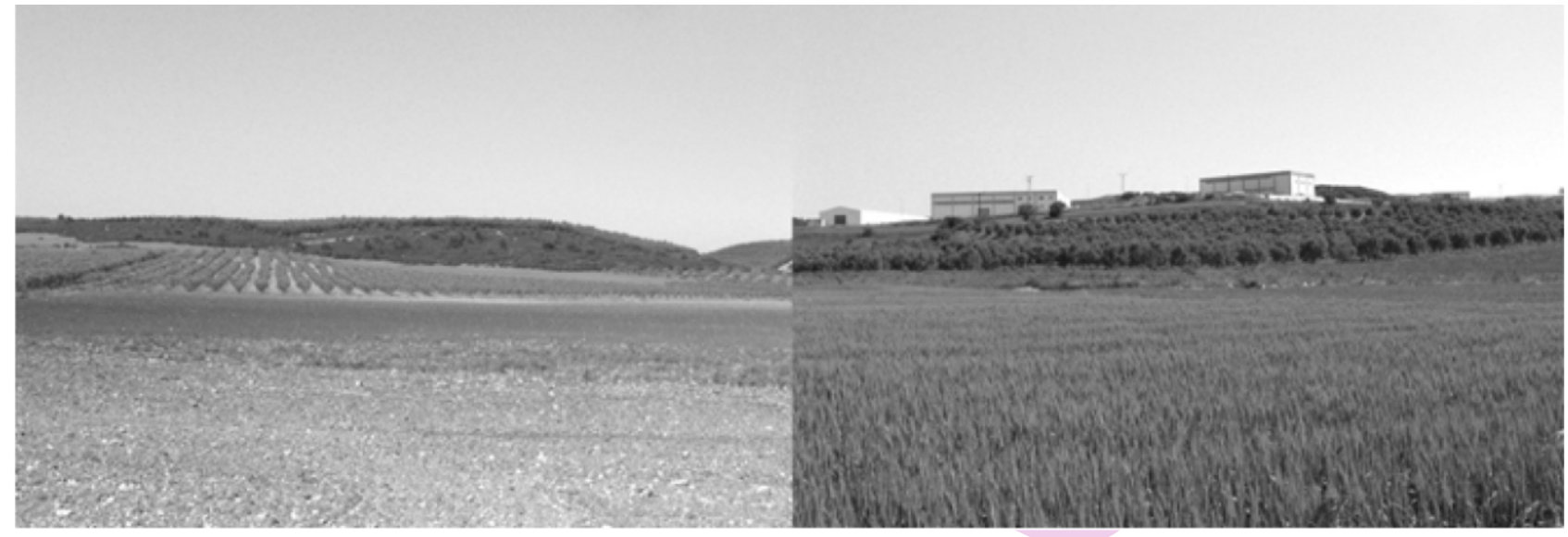

Fig. 17 : Planting and dry farming have gained importance because protection efforts in the basin have significantly limited the use of fertilizers and pesticides (Bulgurca Neighborhood on the left and Tekeli areas on the right)

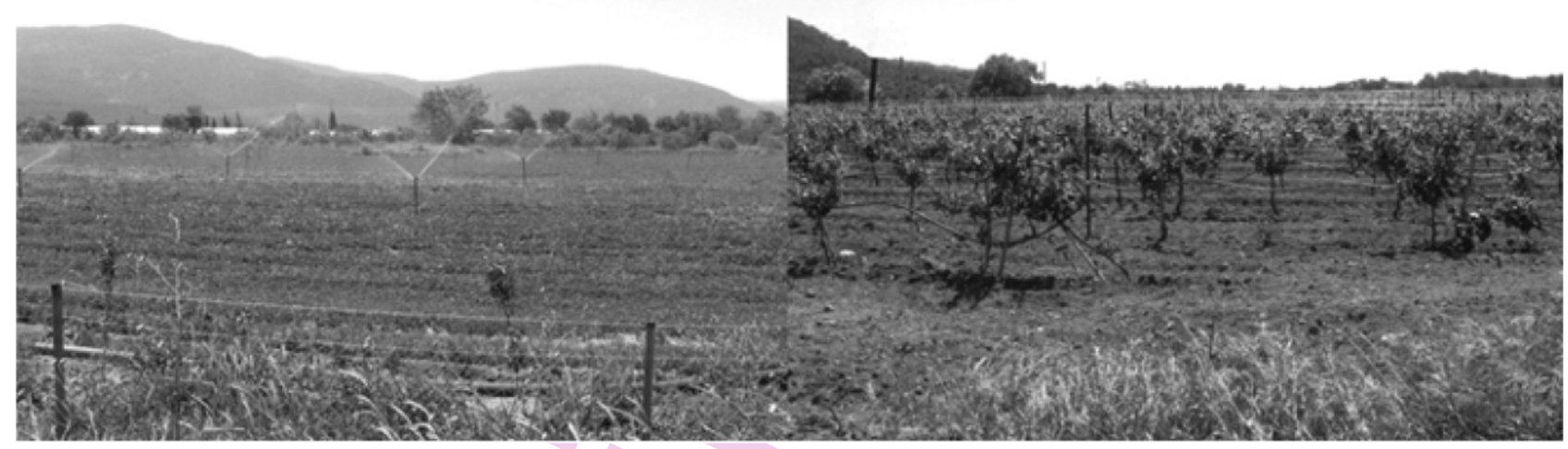

Fig. 18: Irrigated farming is practiced in the long range protection area (Değirmendere Neighborhood on the left and Çatalca Neighborhood on the right)

Class III (14\%), Class VII (11\%), Class IV (2\%), and Class I (0.3\%) lands (Fig. 16). A settlement area for about $4000-5000$ years, the Tahtalı Dam Protection Basin is home to 94.649 people according to data 2015. Menderes, which developed in commerce, agriculture, and transportation, is the most important settlement area, and the Keler Neighborhood is the smallest one with 179 dwellers. Thirty-eight per cent of the basin population lives in the Menderes district center; $62 \%$ inhabits the neighborhoods that are longer considered villages according to the Metropolitan Law. Settlements start on the basin floor, reaching up to 440 meters (Doğancılar Neighborhood) (Fig. 1). Half of the settlements $(52.14 \%)$ in the research area are on the floor basin. Thirty three per cent ( 9 settlements) are on alluvial plains, and 15\% (4 settlements) are on mountain slopes. Houses constitute the bulk of the settlement areas, followed by industrial and commercial facilities. Organized industrial zones and small industrial areas are concentrated in Sarnıç, Tekeli, Kısık, and Oğlananası. ITOB
Organized Industrial Zone in the Tekeli Neighborhood features furniture and woodwork workshops, citrus products, packaging and case manufacturing factories, olive oil combines, poultry businesses, leaf/tobacco workshops, and Pınar Şaşal drinking water processing facilities. The Kısık Köy Organized Industrial Zone contains the new ESTIM (Aegean Industrialists' Commerce and Export Center), which occupies an area of $430.000 \mathrm{~m}^{2}$ and comprises many S.S. İzmir Woodwork Industry sites. In the Aegean Industrialists' Commerce and Export Center, there are 552 metalwork and 300 woodwork businesses. The vegetablefruit market and the fish market in the Kaynaklar Neighborhood of Buca pollute the basin (Fig. 9). In addition, there are privately owned animal farms, poultry farms, sausage and olive oil factories, lime kilns, vegetable packaging and export facilities, and stone chip factories in the Kaynaklar, Kırıklar, Belenbaşı, and Karaağaç neighborhoods. Even though the Sarnıç Neighborhood is located within the boundaries of the Tahtalı Dam Protection 


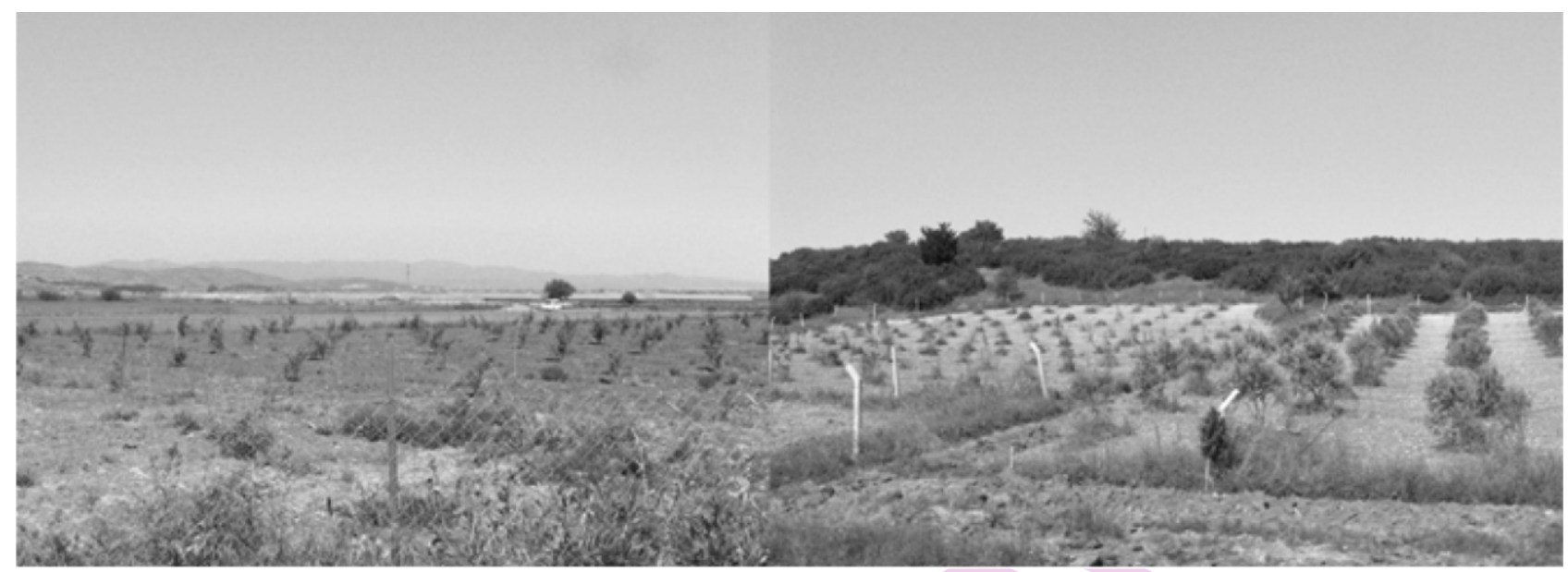

Fig. 19 : The use of the basin floor for planting is a wrong practice. Basin floors are suitable for crop cultivation with rotation whereas alluvial plains are eligible for planting.Planting on the basin floor between the Tekeli and Çileme neighborhoods (misuse) on the left; Planting on alluvial plains (correct use) on the right

Basin, it is home to intense industrial activities. There are 50 large companies with industrial facilities in the area, which produce textiles, furniture, plastics, rubber, packaging materials, storage batteries, marble, flour, and oil (IZTO, 2016). Nearly $70 \%$ (69\%) of settlement areas in the basin are located on Class I, II, III, and IV lands, which are normally supposed to be used as farmlands. This is a clear indication of a mismatch between land use and the land capability classes (Fig. 16 and 19).

Mines and areas where they are extracted are as follows: copper-lead-zinc (Menderes-Gümüşsu, Buca-Kaynaklar), dolomite (Cumaovası-Değirmendere-Çamlıtepe, BucaKaynaklar), manganese (Bulgurca), perlite (CumaovasıKünerköy, Şaşal, Bahçecik, Yeniköy, Yargılı), lignite (Cumaovası), and antimony (Cumaovası). Natural vegetation is damaged in mining sites; excavated materials have been stacked in a disorderly fashion, and pits have not been closed. These areas must be improved as soon as possible.

Water surfaces constitute around 3\% of the Tahtalı Dam Protection Basin. Today, $33 \%$ of water surfaces are on Class I lands, $27 \%$ on Class VII lands, $25 \%$ on Class II lands, and $14 \%$ on Class III lands. Put another way, $4 \%$ of Class I, II, and III lands, which were supposed to be arable as the dam began to accumulate water in 1995, are now submerged.

The relationship between land use and the land capability classes: There is a mismatch between the land capability classes and their use. Class I, II, III, and IV lands that are supposed to be used as farmlands account for $36 \%$, yet farmlands currently cover only $31 \%$ of the area. This may look proportional at first; however, $7 \%$ of Class I, II, III, and IV lands are used for settlement and $4 \%$ for water surfaces, and $34 \%$ are occupied by forests. Furthermore, $18 \%$ of Class V, VI, and VII lands are allocated to agriculture and $2 \%$ to settlements (Fig. 3, 4 and 5).

In other words, there are clear indicators of the misuse of the natural potential of the area. Forty-eight per centof Class I lands are submerged; $1 \%$ is used for settlements, and $15 \%$ are utilized as forest areas. Nine per centof Class II lands are used for settlements; $2 \%$ are submerged, and $24 \%$ are used as forest areas. Six per centof Class III lands are used for settlements; $2 \%$ are under water, and $34 \%$ are used as forest areas. Class VI lands, which are supposed to be used as grasslands, are made use of as farmlands (22\%) and settlement areas (3\%). Despite the protection status of the basin, these areas are turning into degraded lands because of excessive and early grazing. Eightytwo percentof Class VII lands, which are supposed to be used as forests, are composed of maquis and garrigues. Agricultural activities take place on $16 \%$ of these lands, and there are settlements on $1 \%$. Furthermore, $1 \%$ is under water. In other words, $18 \%$ of Class VII lands are misused.

Other examples of the mismatch between land use and the natural potential include the following: $22 \%$ of dry farming areas are on Class VII lands, $17 \%$ of irrigated farmlands are on Class VII lands, $69 \%$ of settlements are located on Class I, II, III, and IV lands, $11 \%$ are on Class VII lands and $20 \%$ on Class VI lands.

This, of course, leads to certain adverse conditions in the basin. For example, severe erosion that afflicts $54 \%$ of the basin significantly affects sloping areas deficient in vegetation (Fig. 7 and 8 ). Twenty-eight percent of the basin is impacted by moderate erosion, and normal erosion occurs on $18 \%$. Severe erosion afflicts degraded areas with $10 \%$ slope, dry farming lands, vicinities of settlement areas, and areas with large mining sites. In the Tahtalı Dam Protection Basin, very severe erosion (88\%) and severe erosion $(75 \%)$ occur mostly in areas where there are 
forests, maquis, and garrigues. This has to do with sparse canopy levels, dry farming practices in the forest-maquis areas, and the creation of olive groves, vineyards, and so on. Also, the occurrence of very severe $(12 \%)$ and severe $(22 \%)$ erosion in agricultural areas is an important matter. To put it another way, severe erosion affects the whole of Class VI lands and almost all Class VII lands. Besides, southern areas made up of metamorphic rocks (marble and schist) and northeastern areas composed of limestones have been subject to soil erosion, which has caused rocks to surface (Atalay, 1989 and 2002; Koçman, 1989). Land degradation brought about by misuse of lands gives rise to biomass loss (Goudie, 2006).

Other consequences of land misuse include occasional overflow on the basin floor, the danger of soil liquefaction after earthquakes, salinity-alkalinity-drainage problems, and basinwide chemical pollution. Pollution is caused in particular by overuse and misuse of fertilizers-pesticides, domestic waste, and waste disposed from industrial facilities near Sarnıç, Kısık, and Tekeli (Barış, 2008)(Fig. 11).

Misuse of lands in the research area has led to discrepant land use types. In fact, agricultural lands on the basin floor and high and sloping areas are degraded. This, in turn, has upset the soil-plant-water balance and decreased biomass production.

The Tahtalı Dam Protection Basin has been used intensively for ages, yet $31 \%$ of it $\left(200 \mathrm{~km}^{2}\right)$ is misused. Severe and very severe erosion takes place in $54 \%$ of the area, and soils lose their fertility and biomass day by day. Besides, $74 \%$ of the research area is sloping, produces low output, and needs improvements.

There is no match between land use and the land capability classes. In other words, socio-economic activities carried out with no consideration of the natural potential of the basin have led to irreversible consequences.

Class VI, VII, and VIII lands, which are unsuitable for farming, are used for agriculture $\left(18 \%, 116 \mathrm{~km}^{2}\right)$ and settlement $\left(2 \%, 13 \mathrm{~km}^{2}\right)$. A portion of arable Class I, II, III, and IV lands is utilized as settlement areas $\left(7 \%, 45 \mathrm{~km}^{2}\right), 4 \%$ of Class I, II, III, and IV lands $\left(6.74 \mathrm{~km}^{2}\right)$ are submerged, and $27 \%$ of Class I, II, and III lands $\left(174 \mathrm{~km}^{2}\right)$, which are supposed to be farmed, are covered with forests-maquis-garrigues, which may look positive as forests function as a cover. However, maquis and, in particular, garrigues do not serve the same purpose. In the forest, oak, and maquis areas, vegetation has been severely degraded due to cutting down of trees and grazing (Fig. 12 and 15). Such forests have become 'degraded forests' (0-10 canopy).Another instance of misuse is the utilization of the basin for planting. While basin floors are suitable for cultivation of field crops with rotation, alluvial plains are better for planting (Fig. 19).
Between 1995 and 2005, the research area saw a 61\% increase in industrial areas, $26 \%$ in settlements, and $350 \%$ in greenhouses (Selçuk and Elçi, 2008). In addition, the increase in the number of illegally built houses (over 5000) in the basin settlements such as the Sarnıç, Görece, Gölcükler, and Gümüş Mestanlı neighborhoods is an apparent violation of the basin protection status (Erdoğan et al., 2008).

Pollution in the basin is caused mostly by agriculture and precipitation-current features. Industrial areas $(0.2 \%$ of the basin), which are significant polluters, are concentrated in the north and northeast of the basin. Areas most prone to pollution include Oğlananası, Küner, Develi on the basin floor, the Yıldız Neighborhood in the north, and the Tahtalı Dam Reservoir. Areas least prone to pollution, on the other hand, are the sections where Görece, Kaynaklar, Karaağaç, and Eski Şaşal neighborhoods are located. The forest cover in the northeast of the basin reduces the pollutant risk in this specific area. The nitrate concentration rises in the straight sections used for agriculture and settlement. However, intense olive farming near Oğlananası and limited farming due to water shortage in the Yildız Neighborhood decrease this concentration. As water carries pollutants during wet seasons, groundwater and dam water quality drops significantly (Barış, 2008; IZSU, 2016). Thus, domestic and industrial wastesincrease the Chemical Oxygen Demand and Biological Oxygen Demand parameters (Fig. 11). The measurements of dam water revealed that the pollution level was higher than that of second class water (Selçuk and Elçi, 2008).

The main purpose of the Tahtalı Dam is to provide drinking water to the city of Izmir. It is also used for irrigation, fishing, grazing and has an aesthetic value, all of which make it important to locals. However, these aspects have been ignored, and protection efforts have focused entirely on the strict protection area. The main pollutants such as chemical fertilizers and pesticides, industrial facilities, and sewage discharge into the dam through the streams in Menderes and other areas have been ignored. On top of these problems, public servants' attitude and behavior toward locals have increasingly led to distrust. Put another way, locals in the dam protection basin have been labelled as the 'main pollutants' by IZSU officials, which masks the real reason behind pollution and the decreasing water quality. Preservation of the water supply and quality and prevention of siltation are only possible with locals' involvement and assistance.

Land degradation has upset soil-plant-water balance in about 1/4 and decreased biomass production in the Tahtalı Dam Protection Basin. Only by creating a land use pattern that is suitable for the natural potential (land capability classes) of the lands could this loss be prevented.

In order to sustain the natural potential in the basin, soils should be used in line with the land capability classes. For 
instance, olive groves should be built on Neogene lacustrine and colluvial deposits, and over $10 \%$ sloping lands on flysch, volcanic rocks, and metamorphic rocks should be used as forests. In addition, drought-tolerant species should be farmed on the basin floor instead of species requiring plenty of water. Pollution maps should be drawn; organic farming should be encouraged, and the water pollution control regulations should be expanded to include groundwater as well. Additionally, rotation should be applied so as to increase output from greenhouses concentrated on the basin floor (Öztekin et al., 2009). Furthermore, farming and animal husbandry in short and long range protection areas should be inspected, and chemical fertilizers and pesticides should be banned. Certified production systems should be employed in order to ensure the sustainability of agriculture and minimize risks of agricultural pollution (Tüzel et al., 2002; Tüzel and Gül, 2008). Helping farmers with marketing operations is also a crucial issue. Promoting certified products in the media could increase domestic demand for them. The basin is close to Adnan Menderes Airport, which is important for import and export. For sustained and organized marketing operations, rural development cooperatives should be established following the example of the 'Bademler Village Agricultural Development Cooperative' (Urla, İzmir) (Gülersoy et al., 2014).

Rural residents of the Tahtalı Dam Basin should be informed of alternative sustainable economic activities (organic farming, ecotourism, etc.) so they make a living and abide by the protection rules at the same time. Economic activities have been severely restricted by protection efforts, hence an autonomous "Tahtalı Dam Protection Basin Forestry Center" should be established, and it should assess human-space interaction and ensure inter-institutional coordination. Furthermore, it is advisable to ramp up interdisciplinary efforts to govern the socioeconomic life. Officials of this prospective center could encourage locals to participate in efforts and should not be put under political pressure from local or national administrative organizations. Efforst also should be spent on comparing and evaluating the initiatives of other countries.

\section{References}

Anderson, J.R., E.E. Hardy and J.T. Roach.: A land-use classification system for use with remote-sensor data. U.S. Geol. Survey Circ., 671, 16 (1972).

Atalay, l.: Impact of rural settlements on land degradation in Turkey. J. Geograp. Res., 1, 91-103 (1989).

Atalay, İ.: Ecological Regions of Turkey. Meta Press, İzmir. Turkey (2002).

Atalay, İ.: Ecology and Geography of Ecosystem. Ministry of Environment and Forestry. Vol. I-II, Meta Press, İzmir. Turkey (2008).

Atalay, İ.: Soils: Development, Classification and Geography. Meta Press, İmir. Turkey (2011).

Atalay, İ. and R. Efe: Structural and distributional evaluation of forest ecosystems in Turkey. J. Environ. Biol., 31, 61-70 (2010).
Atalay, İ. and A.G. Gündüzoğlu: Land capability classification according to ecological conditions of Turkey. Meta Press, İzmir, Turkey (2015).

Ay, Z.K.: Research on landuse policy in long distance protection of area in Tahtalı Dam. İzmir. Ege Univ. Institute of Science unpublished PhD dissertation, İzmir, Turkey (2001).

Berkes, F.: Sacred Ecology: Traditional Ecological Knowledge and Resource Management. Taylor \& Francis, Ann Arbor (1999).

Buca, Gaziemir, Menderes, Torbalı district Agriculture directorates: Agricultural data of Buca, Gaziemir, Menderes, Torbalı districts. Izmir, Turkey (2015).

Burley, T.M.: Land use or land utilization? The Professional Geographer, 13, 18-20 (1961)

Doğanay, H.: Economic Geography of Turkey. Oz Egitim Publishing. Konya (1995)..

Efe, R., A. Soykan, I. Cürebal and S. Sönmez: Land Use and Land Cover Detection in Karinca River Catchment (NW Turkey) Using GIS and RS Techniques, J. Environ. Biol. (Special Issue), 33, 439447(2012).

Efe, R., A. Soykan, I. Cürebal and S. Sönmez: Olive and olive oil in the world, Turkey, in and around Edremit Gulf. $2^{\text {nd }}$ Edn., Akmat Press. ISBN: 978-605-62253-0-7(2013).

Erdoğan, N., Ü. Erdem, F. Doğan and B. Türkyılmaz: The relations of Kucukmenderes sub basin, Tahtalı Dam, Efemcukuru and Camlı dam. Directorate of DSI II. District. Izmir. Proceedings of Basin Pollution Conference, pp. 97-104 (2008).

Erinç, S.: Turkey: Man and Environment. Istanbul University, J. Instit. Geogr., 10, 1-33 (1973).

Eswaran, H., F.H. Beinroth and S.M. Virmani: Resource management domains: A biophysical unit for assessing and monitoring land quality. Agri. Ecosys. Environ., 81, 155-162 (2000).

Feoli, E., P. Giacomich, K. Mignozzi, M. Öztürk and M. Scimone: Monitoring desertification risk with an index integrating climatic and remotely-sensed data: An example from the coastal area of Turkey. Manag. Environ. Qual.: An Int. J., 14, 10-21 (2003).

General Directorate of Rural Services: Total land size. KHGM Publishing. Ankara (2001).

Ghimire, B.K. and M.P. Pimbert (Ed.): Social Change and Conservation, Earthscan Publications Limited, United Kingdom (1997).

Goudie, A.: The Human Impact on The Natural Environment. Blackwell Publishers, Oxford (2006).

Gülersoy, A.E., M.A. Çelik: Determining of areas with high erosion risk in Küçük Menderes River Basin (West Anatolia, Turkey) by using multi-criteria decision making method. Fres. Environ. Bull., 24, 195-202 (2015).

Gülersoy, A.E., N. Gümüş and A. Illhan: From tradition to modernity, from the field to the theater; A Transformation Story: Bademler Village (Izmir). TUCAUM VIII. Geography Symposium. Proceedings, Ankar, pp. 438-448 (2014).

Gülersoy, A.E., N. Gümüş, M.E. Sönmez, G. Gündüzoğlu: Relations between the land use and Land Capability Classification in Küçük Menderes River Basin, J. Environ. Biol. (Special Issue), 36, 17-26 (2015).

Günal, N.: Characteristics of vegetation on the area between Gediz and Buyukmenderes Rivers. Istanbul University. Bull. Mar. Sci. Geogr., 3, 93-104 (1987).

Hockensmith, J.G. and J.G. Steele: Classifying land for conservation farming. Farmers Bulletin No. 1953. USDA, Washington, DC, pp. $1-45(1943)$. 
IZSU: Agriculture notification of Tahtalı Basin. Izmir Metropolitan Municipality, Management of Water and Sewerage. Izmir (1997).

IZSU: Protection Basin of Tahtalı Dam. Izmir (2016).

IZTO: Socio-Economic data of Buca, Gaziemir, Menderes, Torbalı districts (2016).

Kellogg, C.E.: Soil and Land Classification. J. Farm Economics, 33, 499513, 1951.

Koçman, A.: Researches and applied physical geography studies in Izmir-Bozdaglar region. Ege University, Faculty of Letters, Izmir (1989).

Manyari, W.V. and O.A. Carvalho: Environmental considerations in energy planning for The Amazon Region: Downstream effects of Dams. Energy Policy, 35, 6526-6534 (2007).

Öztekin, G.B., Y. Tüzel and H. Teket: An overview of greenhouse vegetable growing in Tahtalı Dam protection basin, Ege University. J. Fac. Agricult., 46, 101-110 (2009).

Öztürk, M.: Recovery and rehabilitation of Mediterranean type ecosystem-Acase study from Turkish maquis. In: Evaluating and Monitoring the Health of Large-Scale Ecosystems, NATO-ARW (Eds. D. Rapport, C.L. Gaudet and P. Calow). Springer- Verlag, pp: 319-332 (1995).

Öztürk, M.: Urban ecology and land degradation. In: Perspectives in Ecology (Ed.:Almo Farina). Backhuys Publishers, Leiden, NL, pp. 115-120 (1999)

Öztürk, M., A. Celik, C. Yarci, A. Aksoy and E. Feoli: An overview of plant diversity, land use and degradation in the Mediterranean region of Turkey. Environ. Manag. Hlth., 13, 442-449 (2002).

Panhalkar, S.: Land capability classification for integrated watershed development by applying remote sensing and GIS techniques. J. Agri. Biol. Sci., 6, 4 (2011).

Selçuk, P. and Ş. Elçi: Analysis of effects of land use on water quality in Tahtalı River Basin. DSI II., District Directorate, Izmir. Basin
Pollution Conference Proceedings, pp. 73-88 (2008).

Sönmez, M.E.: Negative effects of Dams on Space: Cases from Turkey. Gaziantep University. J. Soc. Sci., 11, 213-231 (2012).

Strahler, A. and A. Strahler: Introducing Physical Geography. John Wiley and Sons Publishing, New York, USA (2006).

TOPRAKSU: Soils of Kucukmenderes Basin. Ministry of Rural Affairs and Cooperatives Publishing, 222, Ankara (1974).

TÜBITAK-MAM: Preparation of Watershed Protection Action Plan Project,Kucuk Menderes River Basin. Report of TUBITAK Marmara Reseacrh Center, Institute of Environment. Kocaeli (2010).

TÜIK: Bulletin of Address Based Population Census Results for 2015. Ankara (2015).

Tümertekin, E. and N. Özgüç: Human Geography: Man-Culture-Space, Çantay Publishing, Istanbul (1997).

Tüzel, Y. and A. Gül: Good Agricultural Practices in Greenhouses. Ege Univ. Faculty of Agriculture Publ. Izmir (2008).

Tüzel, Y., A. Gül, O. Tuncay, F. Öztan, Z. Yoldaş, N. Madanlar, B. Durmuşoğlu, E. Örümlü, M. Gümüş, E. Onoğur, S. Engindeniz, H. Tüzel, D. Anaç, B. Okur, B. Yağmur, A.R. Ongun, N. Okur, S. Göçmez, R.Z. Eltez, N. Aykutand H. Gülçin: Organic Greenhouse Vegetable Production Facilities in Tahtalı Dam Protection Basin. TUBITAK Project no. TARP 2577-1, Izmir (2002).

Uzel, B.: Quaternary Geology and Active Tectonics of Cumaovası (Menderes) Basin. Unpublished Master's Thesis, Dokuz Eylul Univ. Inst. Of Sciences. Izmir (2007).

Yılmaz, Y., Ş.C., F. Güner, M. Bozcu, K. Yılmaz, Z. Koracık, Ş. Altunkaynak and A. Elmas.: When did the Western Anatolia grabens begin to develope (Eds.: E. Bozkurt, S.A. Winchester and J.D.A. Piper). Tectonics and magmatism in Turkey and surrounding area, Geological Soc. London, Special Pub., 173, pp. 353-384 (2000). 